\author{
WiOletTA Kilar \\ Pedagogical University of Cracow, Poland
}

\title{
Spatial Concentration of IT Corporation Headquarters
}

\begin{abstract}
This paper analyses spatial concentration of IT corporation headquarters (HQs) with the intention to identify the countries where IT corporation headquarters are concentrated. According to the research, from 2003 to 2011, the most dominant IT corporations had their headquarters in the USA, Japan and Taiwan, as these countries created the best conditions for their operations. In European countries, the highest number of company headquarters was reported in France, Germany and Switzerland. An analysis of the economic potential indicator showed that, over that period, IT corporations were growing dispersed in the global space. The phenomenon manifested itself by a drop in the number of corporations placing their headquarters in the USA and Japan, which translated into dispersed economic potential that, by the time, had been concentrated in these countries. Furthermore, newly emerging corporations from China, Ireland, India, the Netherlands, Mexico and Malaysia increased their importance in the sales structure. The high degree of economic concentration of IT corporations was confirmed by the synthetic metric of the economic potential, calculated on the basis of: the number of corporations, sales value, profit, the value of their assets and their market value.
\end{abstract}

Key words: asset value and market value; economic potential; IT corporation; number of corporations; profit; spatial concentration; synthetic measure

\section{INTRODUCTION}

„In the process of intensifying globalization, the core role is played by the leading corporations who, through their versatile systems of network spatial and production relations organize the global economic space by their rules of development. (...) Here, a particularly important role is played by the headquarters of the leading global companies, who play the role of decision centers. On the basis of accepted strategic assumptions which are based on the process of economic development and foreseeable transformative trends in the global, national or regional, or even local systems, management boards make decisions on: the flow of cash supporting the set direction of R\&D works, new locations, expansion of the existing production capacities, production size, volume and assortment, its modernization, their supply markets and corporate relations, sales markets for finished products, marketing etc." (Zioło, 2006a: 9).

Further to the above-indicated premises, this paper focuses on the spatial concentration of IT corporations. The intention is to identify the place occupied by IT corporations in 
geographic research and analyse changes in the concentration of headquarters of 100 dominant IT companies from 2003 to 2011 by countries.

In particular, the research focused on 100 leading IT corporations selected from 2,000 largest global corporations operating in all types of business sectors. From 2003 to 2011, 231 IT corporations were ranked among 2,000 largest global corporations and their number fluctuated from 142 IT corporations in 2009 to 160 in 2011. In the analysed period, 153 corporations per year on average were classified to the IT sector. 100 leading corporations would be corporations ranking in the top 2,000 largest global corporations in all years of the ranking.

\section{CORPORATIONS IN GEOGRAPHIC RESEARCH}

International corporations are analysed and researched by many scientific disciplines, but mostly by economic (Szymańska, 2005) and geographic sciences. In geographic sciences, the analysed issues are classified to a current in the geography of industry, which forms a part of the economic geography. The contemporary geography of industry is eclectic in nature as, after R. Hayter (1997), it should be assumed that borders between theories are being blurred and concepts, terminology and methods that used to be linked with one theoretical approach are applied and modified in other approaches. T. Stryjakiewicz (1999: 24-27) distinguishes three theoretic and methodological orientations in the geography of industry, which are now self-complimentary: the neoclassical, behavioural and institutional orientation. From the point of view of the analysed issue, the institutional orientation requires a broader description. Contrary to the neoclassical theory, in the theory, goals, priorities and strategies the enterprises are, to a large extent, autonomous in nature and, as a part of the environment, may considerably modify it instead of accepting it passively. The location factors in the theory are not a feature assigned to a place but are the subject of various negotiations and persuasions, e.g. labour costs, prices or tax level (Szymańska, Płaziak, 2014; Płaziak, Szymańska, 2014). According to the theory, the process is controlled by technostructures, i.e. professional, specialized decision-making managing entities which take a variety of actions, e.g. they are responsible for negotiating developments in procedures, market transactions and dealings between governments of states and corporations. The methodological patterns of the institutional orientation research are classified to the intensive group and involve an in-depth analysis of the case studies which bear some distinctive marks. According to many authors, this allows for complete understanding of the comprehensive nature of many processes and their dependence on the internal and external environment. The institutional orientations are closely linked with the geography of enterprises which has been developing since 1960. "This trend in the research emphasises the role of economic organizations (in particular, of large supranational corporations) as the core element shaping the spatial structure and transformations of the industry of the entire economy. B. Domański (1997) calls it the underestimated current of research in the Polish economic geography" (Stryjakiewicz, 1999: 24-25). 
Many authors indicate that this issue refers to the main current of the research in the geography of industry domain, which specifies the role of supranational corporations in the global economy, their impact on changes in network relations of companies which are connected with them, changes in the organization and movement of capital and information (Stryjakiewicz, 2001a; Wieloński, 2003, 2005; Zioło, 2001, 2003, 2004, 2006a, 2006b; Zorska, 1998, 2002, 2007).

In network relations of corporations, and IT corporations in particular, a particularly important role is played by the location of branches, manufacturing plants, subbranches which, located all over the world, are managed by decision-makers from the seats of their management boards (the headquarters) located in sometimes remote countries, regions or metropolises. It is indicated by the emporia research analysing network connections of the industry (Stryjakiewicz, 2001a; Tkocz, 2003; Wieloński, 2004; Zioło, 2003; Paszkowski, 2008; Dorocki, 2010), headquarters of the leading international corporations (Zioło, 2001, 2006a; Zioło, Piróg, 2002; Gierańczyk, Stańczyk, 2003; Stryjakiewicz, 2009; Kilar, 2010b; Lizak, 2010), relations related to the inflow of direct and indirect foreign investment (Domański, 2002; Rachwał, 2003; Sala, 2006; Dorocki, 2011; Kowalska, 2011), emergence of the leading global companies (Wajda, 2003, 2006; Wajda, Zalewska, 2003; Wajda, Zorićić-Wołek, 2003; Kilar, Cieluch, 2008; Kilar, 2009a, 2009b, 2010a, 2010b, 2011a, 2011b; Wójtowicz, 2009, 2010; Zioło, 2009a; Tkocz, Żydzik, 2010; Boguś, 2011a, 2011b; Bonar, 2011) innovative activity of enterprises (Szymańska, 2012) and the impact of the crisis on their operation (Zioło, 2011; Kilar, 2011a, 2011b; Boguś, 2011a, 2011b; Bonar, 2011).

\section{Changes IN THE NUMBER OF IT CORPORATIONS BY COUNTRIES}

Analysing concentration of IT corporations by the number of their headquarters in a country, it was generally observed that, each year, IT corporations tended to center in the USA and their number ranged from 52 corporations in 2003 to 41 corporations in years 2007-2008 and 2010-2011 in the analysed period (Tab. 1).

In the analysed period, approximately $25 \%$ of the corporations were Japanese corporations and 10\% Taiwanese corporations. Other 17 countries hosted headquarters of very few if not one corporation per country.

In 2003, the USA played the dominant role in the structure of countries having the highest number of headquarters (later: HQs) of IT corporations, with 52 corporation headquarters, followed by Japan with the headquarters of 24 analysed IT corporations. In total, 76 headquarters of dominant IT corporations operated in these two countries (Fig. 1). The importance of Taiwan and France, with 8 and 4 corporation headquarters, respectively, was much lower. The remaining 12 corporations kept their headquarters in: South Korea, Germany, Canada, Switzerland, the Bermudas, the Cayman Islands, Finland, Singapore, Sweden and the UK.

Between 2003 and 2011, the number of corporations located in specific countries changed. The highest growth in the number of IT corporation HQs was reported by: South 
Korea, with the number of HQs growing from 2 to 4 corporations, i.e. by $200 \%$, and Switzerland, with the number of HQs growing from 1 to 2 corporations. The USA reported a major reduction in the concentration of IT corporation HQs from 52 to 41 , i.e. to $78.8 \%$ while in Japan, the number of IT corporation HQs dropped from 24 to 21, i.e. to $87.5 \%$. In total, the number of analysed corporations having their HQs in these two countries dropped from 76 to 62 , i.e. to $81.6 \%$. In Taiwan, the number of HQs of the corporations ranged from 6 to 11 (Fig. 1). A relatively fixed stable number of IT corporations headquartered in their territory was reported by France (3 to 4 corporations), India ( 2 to 3 corporations), Germany (1 to 3 corporations), Canada ( 1 to 2 corporations), Switzerland (1 to 2 corporations), the Bermudas ( 0 to 2 corporations), the Cayman Islands ( 0 to 2 corporations), Finland, Singapore, Sweden and the Netherlands (1 corporation each). In 2003 and 2004, the UK headquartered one of the analysed corporations which, later on, dropped from the structure of dominant corporations. There was a new trend of new countries emerging from 2007 to 2011, hosting the HQs of IT corporations, i.e. Mexico, Ireland and Malaysia as, in that period, some corporations, chiefly due to deteriorating economic conditions, began their search for new locations for their HQs, e.g. in 2010, Accenture moved its HQs from the Bermudas to Ireland. Moreover, cities from these countries are marked by strong international links manifesting itself both in the significant number of headquarters and branches of the world's largest companies (Raźniak, 2012; Raźniak, Winiarczyk-Raźniak, 2013).

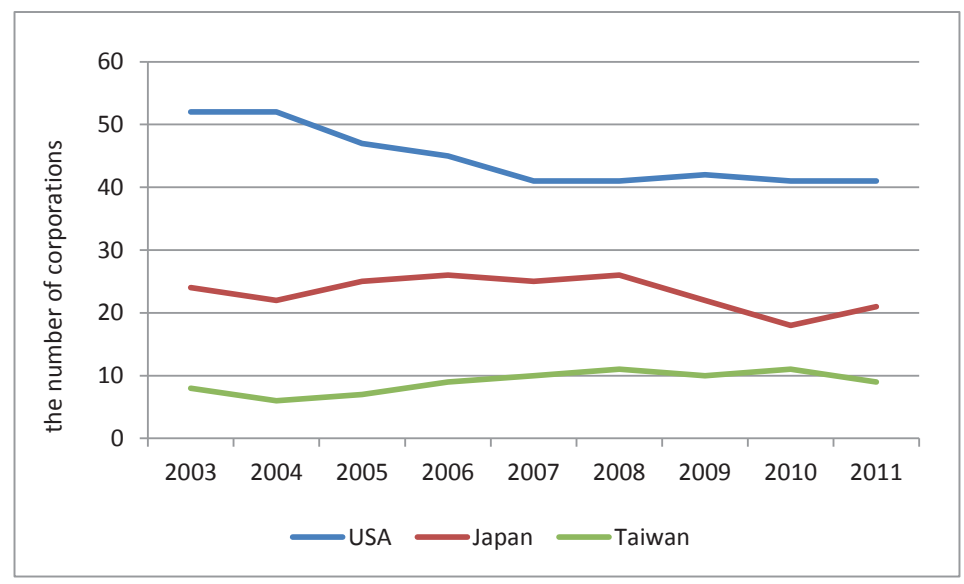

Fig. 1. Growth in the number of IT corporations in the USA, Japan and Taiwan in years 2003-2011 Source: own study

A slightly different structure was typical for the dominant IT corporations in 2011. The number of HQs of the corporations continued the highest in the USA and Japan with 41 and 21 dominant IT corporations, respectively, coming up to 62 analysed corporations. From 9 to 4 corporations were located in Taiwan, China, France and South Korea (Fig. 2). The remaining 16 corporations kept their headquarters in: India, Germany, Switzerland, the Netherlands, 


\begin{tabular}{|c|c|c|c|c|c|c|c|c|c|c|c|c|c|c|c|c|c|c|c|c|c|c|}
\hline \multirow{9}{*}{ 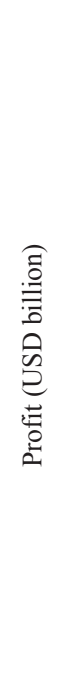 } & I I0Z & 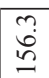 & $\begin{array}{l}0 \\
0 \\
0\end{array}$ & \begin{tabular}{|c|} 
\\
Na
\end{tabular} & $\vec{i}$ & \begin{tabular}{|l|} 
\\
$\vdots$ \\
0
\end{tabular} & $\stackrel{+}{\dot{f}}$ & \begin{tabular}{|l}
$\stackrel{\circ}{+}$ \\
\end{tabular} & \begin{tabular}{|l|} 
\\
\end{tabular} & त) & $\stackrel{\infty}{-}$ & & & $\stackrel{n}{\rightarrow}$ & \begin{tabular}{|l}
$n$ \\
0
\end{tabular} & \begin{tabular}{|l|}
$\infty$ \\
\\
\end{tabular} & 9 & \begin{tabular}{|c|}
$m$ \\
$m$
\end{tabular} & $\overrightarrow{\vec{i}}$ & $\tilde{0}$ & & $\begin{array}{l}\infty \\
\stackrel{\text { in }}{\text { ते }}\end{array}$ \\
\hline & 0I0Z & \begin{tabular}{l}
\multirow{2}{*}{} \\
$\dot{m}$
\end{tabular} & $\stackrel{\circ}{\circ}$ & \begin{tabular}{|c|}
$\dot{\sim}$ \\
$\ddot{\sim}$
\end{tabular} & $\because$ & \begin{tabular}{|l|}
$\mathfrak{o}$ \\
\end{tabular} & $\stackrel{+}{+}$ & $\begin{array}{l}n \\
i \\
i\end{array}$ & \begin{tabular}{|l|}
$m$ \\
$m$
\end{tabular} & ñ & $\stackrel{\circ}{i}$ & $\hat{o}$ & & $\begin{array}{l}n \\
n \\
\end{array}$ & $\stackrel{\circ}{\circ}$ & I & $\stackrel{\nabla}{-}$ & $\vec{m}$ & & $\stackrel{\circ}{\circ}$ & & $\begin{array}{l}\infty \\
\stackrel{0}{\circ} \\
\stackrel{2}{2}\end{array}$ \\
\hline & $600 z$ & กֵ & ఫे & \begin{tabular}{|l|}
$n$ \\
$\infty$ \\
$\infty$
\end{tabular} & $\because$ & $\begin{array}{l}0 \\
0\end{array}$ & $\dot{\varphi}$ & $\stackrel{\circ}{-}$ & $\begin{array}{l}0 \\
i \\
i\end{array}$ & $\stackrel{\tilde{i}}{\mathrm{i}}$ & $\stackrel{Y}{+}$ & $\stackrel{t}{\circ}$ & $\exists$ & $\stackrel{n}{-}$ & $\begin{array}{l}\infty \\
i \\
i\end{array}$ & $\because$ & & $\stackrel{0}{-}$ & $\stackrel{+}{0}$ & & & $\frac{a}{\infty}$ \\
\hline & $800 z$ & $\stackrel{\infty}{\stackrel{\infty}{N}}$ & $\underset{\dot{\sim}}{\stackrel{0}{*}}$ & $\stackrel{+}{\Xi}$ & ?ु & $\begin{array}{l}N \\
\infty\end{array}$ & $\vec{n}$ & \begin{tabular}{|l|l|} 
\\
0
\end{tabular} & $\begin{array}{l} \\
i \\
i\end{array}$ & $\stackrel{\infty}{-}$ & $\hat{\varphi}$ & $\stackrel{\sim}{i}$ & $\tilde{\circ}$ & \begin{tabular}{|l|} 
\\
$\dot{n}$
\end{tabular} & $\hat{i}$ & $\stackrel{+}{-}$ & $n$ & & $\tilde{0}$ & & & స్ర \\
\hline & $\angle 00 Z$ & ๙ু & aे & $\stackrel{?}{=}$ & $\stackrel{+}{i}$ & \begin{tabular}{|l|}
$\infty$ \\
$\stackrel{0}{0}$
\end{tabular} & \begin{tabular}{|l|}
$n$ \\
$i$
\end{tabular} & ?3. & \begin{tabular}{|c|}
$\vec{i}$ \\
\end{tabular} & $\stackrel{+}{+}$ & ?n & $\stackrel{\infty}{-\infty}$ & $\stackrel{i}{i}$ & $\begin{array}{l}n \\
0 \\
0\end{array}$ & $\stackrel{+}{0}$ & $\ddot{r}$ & $\stackrel{\circ}{\circ}$ & & 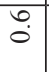 & & & $\begin{array}{l}9 \\
\dot{v} \\
\end{array}$ \\
\hline & $900 z$ & $\stackrel{\infty}{2}$ & $\begin{array}{l}\stackrel{0}{\mathrm{I}} \\
\mathrm{J}\end{array}$ & $\stackrel{\Upsilon}{r}$ & $\because$ & $\stackrel{+}{\sigma}$ & $I$ & & $\begin{array}{l}0 \\
i \\
i\end{array}$ & $\hat{i}$ & \begin{tabular}{|l|} 
\\
0
\end{tabular} & & $\stackrel{\circ}{-}$ & in & $\stackrel{t}{0}$ & $\stackrel{\infty}{\infty}$ & $\stackrel{\infty}{\circ}$ & & & & & 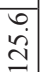 \\
\hline & $\varsigma_{00 Z}$ & $\stackrel{n}{\stackrel{n}{2}}$ & $\stackrel{n}{=}$ & †े & $\stackrel{+}{0}$ & \begin{tabular}{|l|}
$\infty$ \\
$i$ \\
\end{tabular} & $\stackrel{?}{-}$ & & $\stackrel{+}{\stackrel{+}{*}}$ & $\vec{i}$ & ?? & $?$ & $\exists$ & $\stackrel{n}{+}$ & כू & $\vec{m}$ & $\stackrel{t}{0}$ & & & & & \begin{tabular}{|l} 
\\
\\
\end{tabular} \\
\hline & $+00 z$ & ثं & $\stackrel{m}{r}$ & $\hat{m}$ & ก้ & $\stackrel{9}{\circ}$ & $\tilde{0}$ & & $\stackrel{9}{-}$ & $\stackrel{t}{0}$ & $\hat{\circ}$ & $\tilde{0}$ & ?? & \begin{tabular}{|l|}
+ \\
\end{tabular} & $\stackrel{n}{0}$ & $\hat{i}$ & $\stackrel{m}{0}$ & & & & 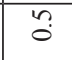 & $\begin{array}{l}m \\
\dot{J}\end{array}$ \\
\hline & $\varepsilon 00 \tau$ & 商 & 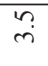 & $\bar{i}$ & $m_{i}^{m}$ & $\stackrel{m}{+}$ & & & $\dot{0}$ & $\ddot{0}$ & ?े & $\stackrel{\circ}{\circ}$ & $\tilde{\sigma}$ & \begin{tabular}{|l|}
$\stackrel{+}{*}$ \\
\end{tabular} & $\begin{array}{l}+ \\
\\
\end{array}$ & \begin{tabular}{|l|}
$\tilde{i}$ \\
$\tilde{i}$
\end{tabular} & & & & & ?ै & 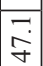 \\
\hline \multirow{9}{*}{ 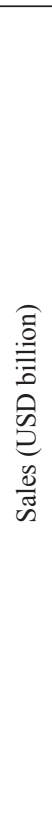 } & I I0Z & $\begin{array}{l}N \\
\stackrel{+}{*} \\
\stackrel{2}{o}\end{array}$ & $\begin{array}{l}\stackrel{\circ}{\sim} \\
\stackrel{\sim}{\sim}\end{array}$ & 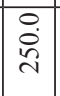 & $\overline{\mathrm{d}}$ & \begin{tabular}{|l|}
$\dot{0}$ \\
$\stackrel{\vec{\sim}}{\sim}$
\end{tabular} & $\begin{array}{ll} \\
\\
\dot{\sim}\end{array}$ & 苍 & \begin{tabular}{|l|}
$\infty$ \\
$\ddot{\lambda}$ \\
$\dot{v}$
\end{tabular} & \begin{tabular}{|l|}
$\infty$ \\
$\stackrel{\infty}{a}$
\end{tabular} & $\stackrel{+}{\sim}$ & & & $\overrightarrow{\mid c}$ & ते & \begin{tabular}{l|}
$\hat{i}$ \\
mे
\end{tabular} & $?$ & $\overrightarrow{\dot{q}}$ & $\overrightarrow{\dot{m}}$ & in & & 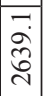 \\
\hline & 0I0Z & $\begin{array}{l}+\dot{0} \\
\dot{\infty} \\
\dot{\sigma}\end{array}$ & 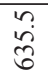 & \begin{tabular}{|c|}
\multirow{3}{*}{} \\
\multirow{2}{*}{} \\
\end{tabular} & \begin{tabular}{|l|}
$\infty$ \\
$\dot{\sigma}$
\end{tabular} & \begin{tabular}{|l|}
$\infty$ \\
$\infty$ \\
$\sim$ \\
$\sim$
\end{tabular} & $\stackrel{2}{I}$ & $\frac{n}{2}$ & $\stackrel{\sim}{\sim}$ & $\begin{array}{l}+\dot{0} \\
\stackrel{\infty}{\sim}\end{array}$ & $\hat{\tilde{i}}$ & $\stackrel{\vec{r}}{\dot{m}}$ & & 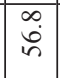 & \begin{tabular}{|l|}
\multirow{2}{*}{} \\
$\stackrel{+}{+}$
\end{tabular} & \begin{tabular}{|c|}
$?$ \\
0 \\
$\tilde{n}$ \\
\end{tabular} & : & 啇 & & $\vec{n}$ & & \begin{tabular}{|l|} 
\\
$\stackrel{\infty}{\alpha}$ \\
$\tilde{\curvearrowright}$
\end{tabular} \\
\hline & $600 z$ & $\tilde{\bigotimes}_{\infty}$ & $\begin{array}{l}\vec{\infty} \\
\widehat{\infty}\end{array}$ & $\begin{array}{c}- \\
\infty \\
0 \\
-\end{array}$ & $\vec{G}$ & \begin{tabular}{|l|} 
\\
i \\
0
\end{tabular} & \begin{tabular}{|l|} 
\\
\\
\end{tabular} & $\begin{array}{l}n \\
\stackrel{n}{0} \\
\end{array}$ & 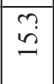 & $\stackrel{?}{ \pm}$ & $\vec{a}$ & $\begin{array}{l}\infty \\
i\end{array}$ & $\vec{m}$ & $\mid \begin{array}{l}\hat{\infty} \\
i n\end{array}$ & ते & \begin{tabular}{|l|}
$\infty$ \\
$\infty$ \\
$\infty$ \\
$\sim$
\end{tabular} & & $\begin{array}{l}n \\
\tilde{n}\end{array}$ & $\stackrel{m}{n}$ & & & $\begin{array}{l}0 \\
\text { in } \\
\tilde{c} \\
\end{array}$ \\
\hline & $800 z$ & $\overrightarrow{+}$ & $\begin{array}{l}n \\
\underset{j}{\infty} \\
\infty\end{array}$ & $\begin{array}{l}0 \\
\text { I } \\
I\end{array}$ & $\begin{array}{l}m \\
0\end{array}$ & \begin{tabular}{|l|}
$\dot{0}$ \\
$\dot{g}$ \\
$=$
\end{tabular} & \begin{tabular}{|l|} 
\\
$\dot{ \pm}$ \\
\end{tabular} & $\overrightarrow{\ddot{v}}$ & $\overrightarrow{6}$ & $n$ & $\hat{a}$ & 㐫 & $\ddot{n}$ & \begin{tabular}{|l|} 
\\
$\stackrel{0}{r}$
\end{tabular} & ते & \begin{tabular}{|l}
0 \\
$\dot{\omega}$ \\
$\stackrel{1}{*}$
\end{tabular} & $\overrightarrow{+}$ & & $\vec{m}$ & & & $\begin{array}{l}n \\
\mathrm{~s} \\
\stackrel{n}{n}\end{array}$ \\
\hline & $\angle 00 Z$ & $\begin{array}{l}+\dot{0} \\
\stackrel{\infty}{\infty} \\
\infty\end{array}$ & 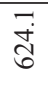 & $\begin{array}{l}\hat{\check{I}} \\
\mathrm{I}\end{array}$ & $\stackrel{n}{2}$ & \begin{tabular}{|l|}
$\dot{0}$ \\
$\dot{8}$ \\
\end{tabular} & $\begin{array}{l}\circ \\
\\
\end{array}$ & \begin{tabular}{|l|} 
\\
$\dot{\Xi}$ \\
\end{tabular} & $\begin{array}{l}\vec{\lambda} \\
\grave{i}\end{array}$ & $\begin{array}{l}\dot{g} \\
\dot{g}\end{array}$ & \begin{tabular}{|l|}
$\infty$ \\
$\stackrel{0}{0}$
\end{tabular} & 它 & $\begin{array}{l}n \\
n\end{array}$ & $\begin{array}{l}n \\
\stackrel{I}{r}\end{array}$ & $\begin{array}{l}n \\
\dot{\sim} \\
\end{array}$ & $\overrightarrow{\mathrm{d}}$ & $\begin{array}{l}\dot{0} \\
\text { in }\end{array}$ & & $\begin{array}{l}\dot{r} \\
\dot{r}\end{array}$ & & & 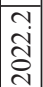 \\
\hline & $900 z$ & $\overrightarrow{+}$ & $\begin{array}{l} \\
\text { in } \\
\text { in }\end{array}$ & $\frac{m}{a}$ & $\stackrel{+}{m}$ & \begin{tabular}{|c|}
$t$ \\
$\dot{\infty}$ \\
$\infty$
\end{tabular} & $\stackrel{n}{\sim}$ & & $\overrightarrow{\mid \vec{\infty}}$ & $\vec{m}$ & $\stackrel{m}{\varrho}$ & & $\stackrel{+}{\underset{I}{J}}$ & \begin{tabular}{|c|}
$m$ \\
$\stackrel{n}{n}$ \\
\end{tabular} & $\begin{array}{l}n \\
\stackrel{2}{2}\end{array}$ & \begin{tabular}{|l|} 
\\
$\dot{\omega}$
\end{tabular} & $\stackrel{\substack{\infty \\
+}}{ }$ & & & & & \begin{tabular}{|l|}
$n$ \\
$\stackrel{n}{2}$ \\
\end{tabular} \\
\hline & $\varsigma_{00 Z}$ & $\stackrel{\infty}{\vec{N}}$ & $\stackrel{n}{n}$ & \begin{tabular}{|c|} 
\\
in
\end{tabular} & \begin{tabular}{|l|}
$\stackrel{0}{+}$ \\
$\dot{m}$
\end{tabular} & \begin{tabular}{|l|}
0 \\
$\infty$ \\
0 \\
\end{tabular} & $\vec{i}$ & & \begin{tabular}{|c|}
\multirow{\infty}{*}{} \\
\end{tabular} & \begin{tabular}{|l|}
0 \\
$\dot{0}$ \\
\end{tabular} & \begin{tabular}{|l|}
$n$ \\
$\infty$ \\
\end{tabular} & $\stackrel{\sim}{2}$ & $\begin{array}{l}n \\
\infty \\
\infty\end{array}$ & \begin{tabular}{|l|}
\multirow{g}{*}{} \\
\multirow{2}{*}{}
\end{tabular} & \begin{tabular}{|l|}
0 \\
\\
\end{tabular} & $\vec{a}$ & $\stackrel{\text { ले }}{\text { r. }}$ & & & & & $\begin{array}{l}\overrightarrow{2} \\
\hat{2} \\
\underline{6}\end{array}$ \\
\hline & $t 00 z$ & 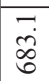 & $\begin{array}{l}n \\
\stackrel{1}{1} \\
n\end{array}$ & 竔 & \begin{tabular}{|l|}
$n$ \\
$m$ \\
$m$
\end{tabular} & \begin{tabular}{|c|}
$\infty$ \\
$\infty$ \\
$\infty$ \\
\end{tabular} & \begin{tabular}{|l|}
$\infty$ \\
$i$
\end{tabular} & & $\stackrel{\sim}{a}$ & $\stackrel{n}{=}$ & $\tilde{a}$ & $\begin{array}{l}0 \\
\stackrel{2}{2}\end{array}$ & $\overrightarrow{6}$ & $\hat{\dot{m}}$ & $\overrightarrow{6}$ & $\dot{\partial}$ & $\stackrel{\nabla}{r}$ & & & & $\stackrel{\circ}{=}$ & $\begin{array}{l}n \\
\hat{2} \\
n\end{array}$ \\
\hline & $\varepsilon 00 Z$ & \begin{tabular}{|l|} 
\\
\\
0
\end{tabular} & r্ & \begin{tabular}{|l|}
$\vec{i}$ \\
in
\end{tabular} & ণ্ं. & \begin{tabular}{|l|}
\multirow{H}{*}{} \\
in
\end{tabular} & & & $\begin{array}{l}0 \\
\\
\end{array}$ & \begin{tabular}{|l}
$?$ \\
0
\end{tabular} & \begin{tabular}{|l|} 
\\
$\infty$
\end{tabular} & $\begin{array}{l}\dot{0} \\
\dot{\sim}\end{array}$ & $\hat{\sigma}$ & $\vec{n}$ & \begin{tabular}{|l|}
$\infty$ \\
\end{tabular} & \begin{tabular}{|l}
$\infty$ \\
0 \\
\end{tabular} & & & & & å & $\begin{array}{l}\vec{a} \\
\stackrel{+}{J} \\
\vec{c}\end{array}$ \\
\hline \multirow{9}{*}{ 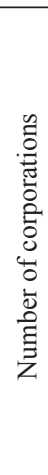 } & I I0Z & $\bar{F}$ & $\vec{\sim}$ & $a$ & 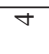 & 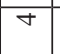 & $m$ & \begin{tabular}{|l|}
$n$ \\
\end{tabular} & 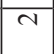 & - & $N$ & & & - & - & - & - & 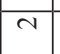 & - & - & & 8 \\
\hline & 0I0Z & $\vec{\gamma}$ & $\infty$ & $=$ & $\sigma$ & 0 & $m$ & \begin{tabular}{|l|l|}
+ \\
\end{tabular} & 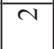 & - & $N$ & - & & 7 & -1 & - & - & $N$ & & - & & 8 \\
\hline & $600 z$ & F & กี & 은 & $\sigma$ & $N$ & $m$ & in & -7 & - & $N$ & - & $N$ & -1 & - & - & & - & - & & & 8 \\
\hline & 8007 & $\bar{F}$ & i & $=$ & $\sigma$ & \begin{tabular}{|l|} 
\\
\end{tabular} & $m$ & 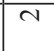 & -7 & - & - & $N$ & -1 & - & -7 & - & - & & - & & & 8 \\
\hline & $\angle 00 Z$ & $\vec{\gamma}$ & $\tilde{\sim}$ & 으 & 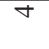 & \begin{tabular}{|l|} 
\\
\end{tabular} & $m$ & - & $N$ & $N$ & - & $\sim$ & $N$ & -1 & - & - & - & & -1 & & & 8 \\
\hline & $900 z$ & y & i & $a$ & $m$ & $N$ & $m$ & & $m$ & \begin{tabular}{|l|} 
\\
\end{tabular} & - & & $N$ & - & - & - & -1 & & & & & 8 \\
\hline & $\varsigma 00 Z$ & F & $\approx$ & $r$ & $m$ & t & $m$ & & $N$ & - & - & $N$ & - & -7 & -1 & - & - & & & & & 8 \\
\hline & $t 00 z$ & ก & ก & 0 & $m$ & $m$ & $N$ & & $N$ & 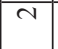 & - & - & - & -7 & - & - & - & & & & - & 8 \\
\hline & $\varepsilon 00 Z$ & กี & $\stackrel{+}{\sim}$ & $\infty$ & 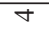 & $N$ & & & $N$ & - & - & - & - & -1 & - & - & & & & & - & 8 \\
\hline \multicolumn{2}{|c|}{$\begin{array}{l}\text { 音 } \\
\text { 它 }\end{array}$} & 死 & 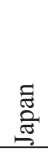 & 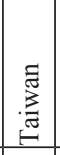 & $\begin{array}{l}\ddot{U} \\
\text { 荀 } \\
\text { 至 }\end{array}$ & 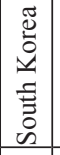 & $\stackrel{g}{g}$ & 尝 & 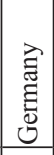 & 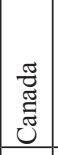 & 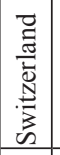 & : & 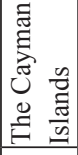 & $\mid \begin{array}{l}\vec{\Xi} \\
\text { 言 } \\
\text { 运 }\end{array}$ & 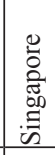 & $\left|\begin{array}{l}\tilde{D} \\
\bar{d} \\
0 \\
0 \\
\tilde{n}\end{array}\right|$ & 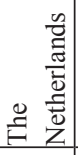 & $\mid \begin{array}{l}\vec{\Xi} \\
\stackrel{\Xi}{\Xi} \\
\stackrel{\Xi}{\Xi}\end{array}$ & 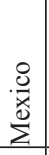 & 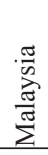 & 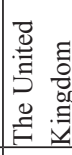 & $\mid \begin{array}{c}\vec{\pi} \\
0 \\
0\end{array}$ \\
\hline \multicolumn{2}{|c|}{$z^{2}$} & - & $\mathrm{N}$ & $m$ & $\nabla$ & $n$ & 0 & $r$ & $\infty$ & $a$ & 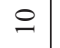 & $=$ & $\simeq$ & 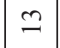 & \pm & $\cong$ & $\stackrel{0}{-}$ & $=$ & $\stackrel{\infty}{\sim}$ & 2 & 가 & \\
\hline
\end{tabular}




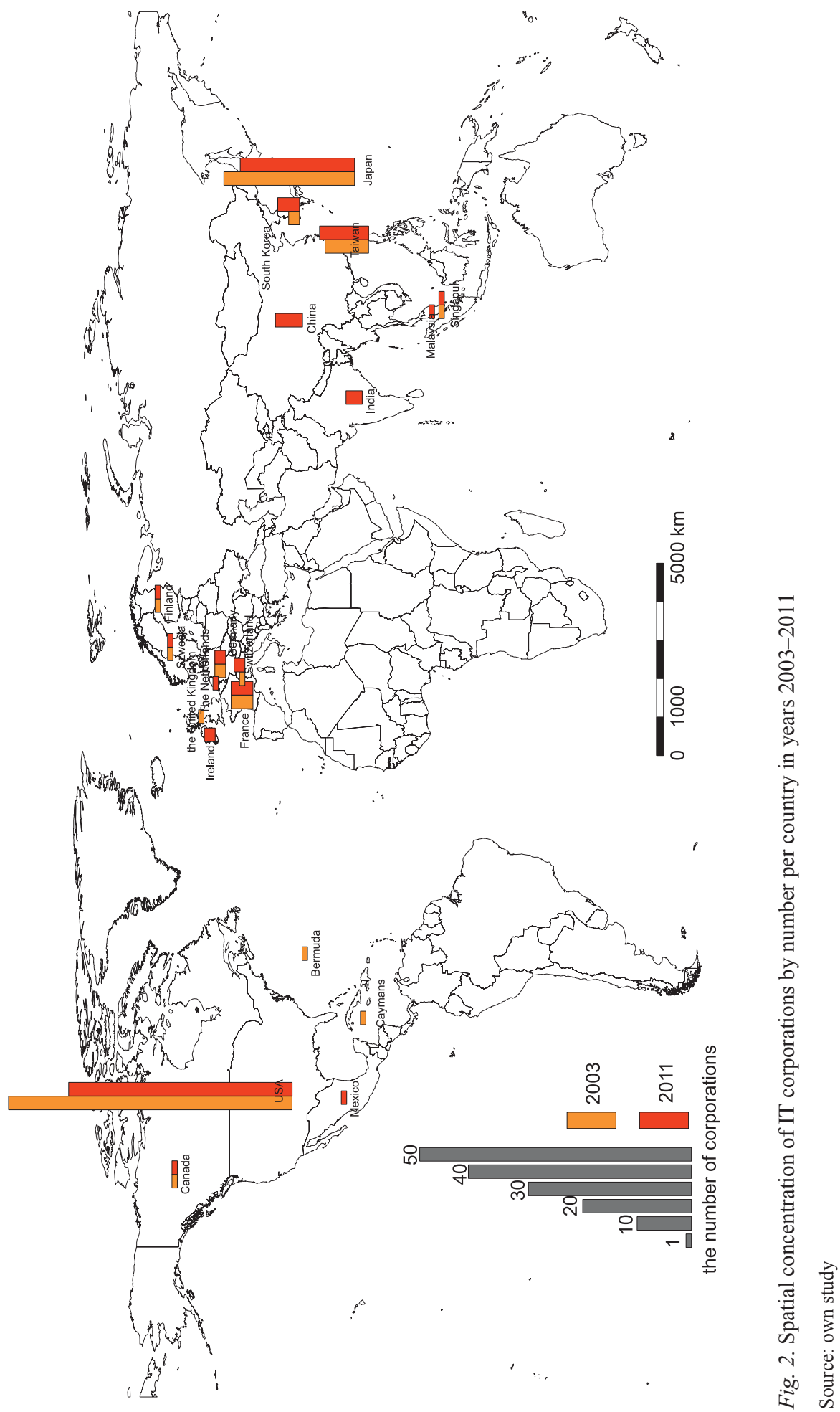


Ireland, Malaysia, Mexico, Singapore, Sweden, Finland and Canada. Some HQs emerged in the structure in countries which, in 2003, did not report any HQs of dominant IT corporations, i.e. China, India, the Netherlands, Ireland, Mexico and Malaysia, characterised by particularly favourable conditions offered to high-tech companies.

Concluding, the analysis shows that the headquarters of leading companies tend to group in the USA, Japan and Taiwan. Note that the importance of European countries is rather low, indicating marginalisation of this part of the world when it comes to creating favourable conditions for setting up and growing modern corporations of such type.

\section{Changes in the Sales Value of IT CORPorations by COUnTRies}

In years 2003-2011, the sales value of the analysed corporations went up from USD 1,324.9 billion to USD 2,639.1 billion, i.e. up to $199.1 \%$. It represented from $90.4 \%$ of sales of all the IT corporations included in Forbes 2,000 rating in 2003 to $86.2 \%$ reported in 2011, indicating a shrinking share in the sales of the leading IT corporations when compared to the total leading corporations of the sector.

As the analysed IT corporations are based in the USA, the analysed period saw clearly the dominance of USA-based corporations with their sales growing from USD 607.8 billion to USD 1054.2 billion, i.e. up to $173.4 \%$. Their share in the total sales dropped from $45.9 \%$ to $39.9 \%$ (Tab. 2, Fig. 3). It can be interpreted as a significant weakening of the sales potential concentration processes in the USA when compared to the total growth value. A lower sales value was reported by Japanese corporations with their sales value going up from USD 463 billion to USD 743.0 billion, i.e. up to $160.2 \%$ and their share dropped from $25.0 \%$ to $28.2 \%$. In total, these countries maintained their dominant role in sales value while their aggregate share dropped from $80.9 \%$ to $68.1 \%$, i.e. by $12.8 \%$. Corporations with their HQs in Taiwan were also important for the total sales because of their rapid growth from USD 28.1 billion to USD 250.0 billion, i.e. up to $889.7 \%$, while corporations in South Korea reported a growth in their sales from USD 54.2 billion USD to 219.6 billion USD, i.e. up to $405.2 \%$. The aggregate value of sales generated by corporations from these two countries increased from USD 82.3 billion to USD 469.6 billion, i.e. up to $570.6 \%$ and their share in the total value of sales came up from $6.2 \%$ to $17.8 \%$. It signifies that the role of intensively growing corporations from Asian countries has begun to grow, while the importance of corporations headquartered in the USA and Japan, which so far dominated the market, has been going down. The importance of corporations from France and Finland was considerably lower in years 2003-2011 sales structure with 5.1\% to 5.8\% of their total sales. The remaining share in the sales value was contributed by corporations headquartered in: Germany, the Bermudas, Sweden, Singapore, Canada, the UK, Switzerland and the Cayman Islands. The economic crisis caused some turmoil in the process, in particular in 2009 , resulting in reduction of the sales value of the corporation. 


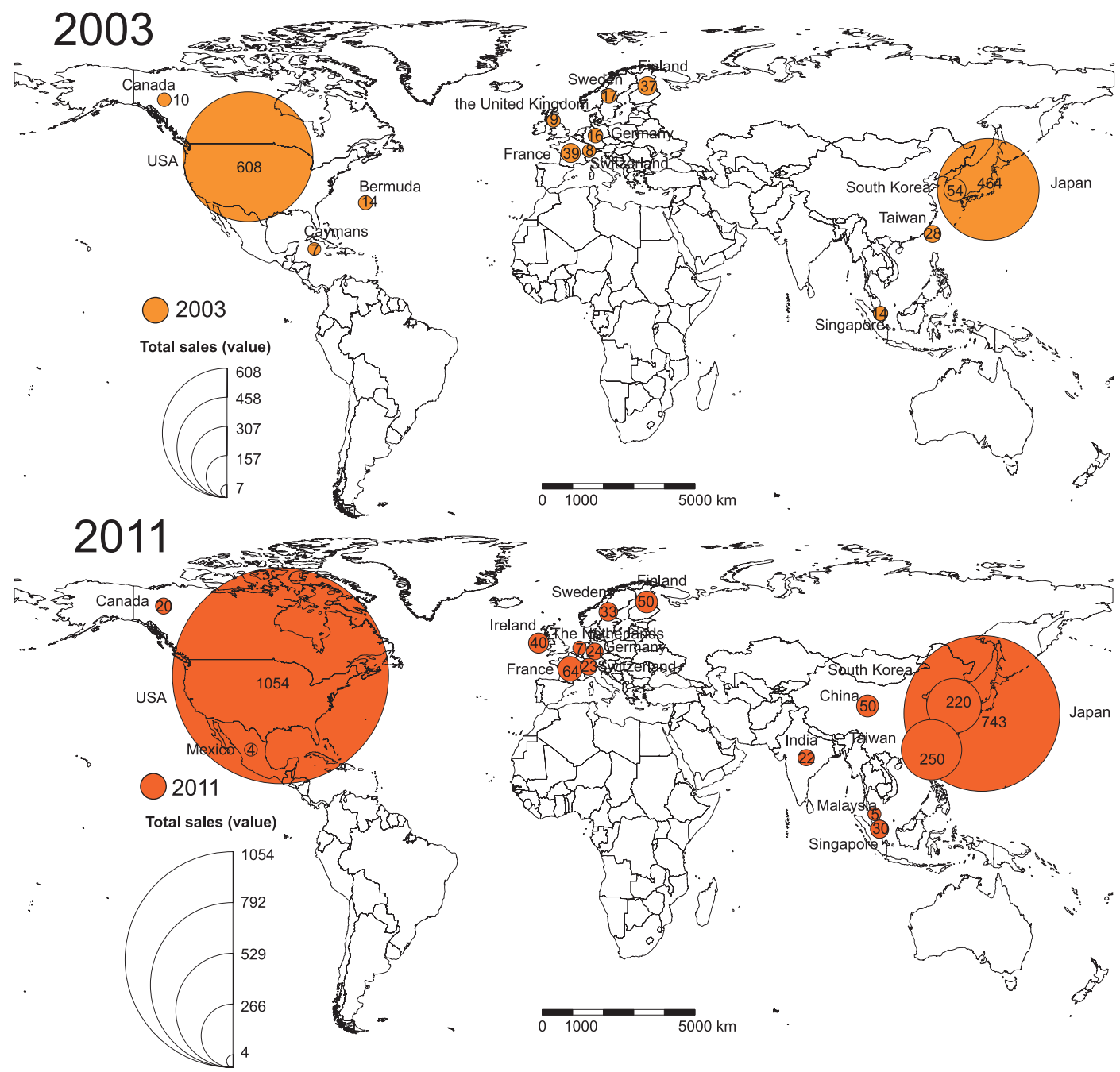

Fig. 3. Differentiation of the sales value generated by IT corporations by countries in years 20032011

Source: own study 


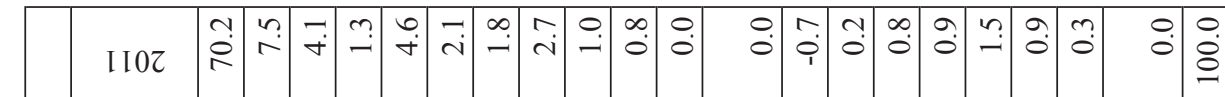

0102000

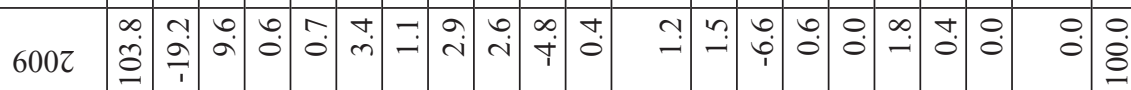

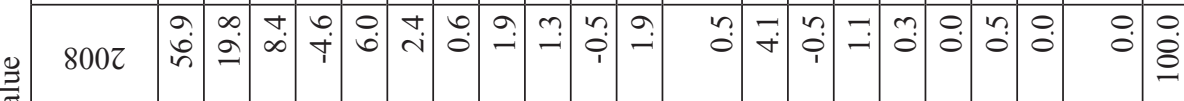

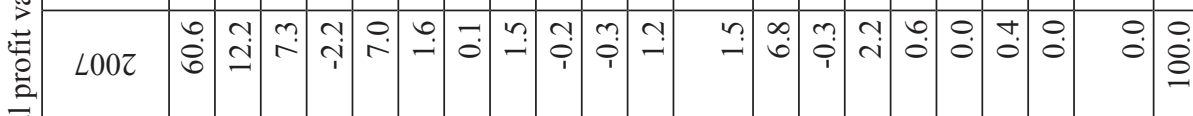

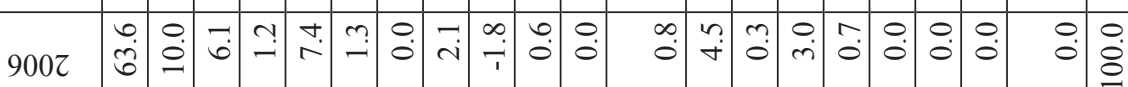

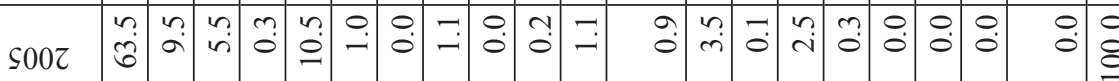

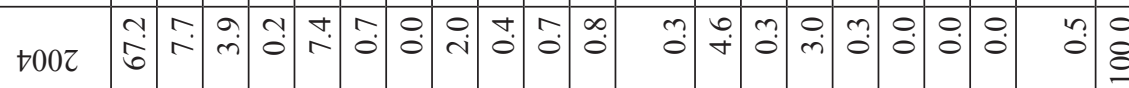

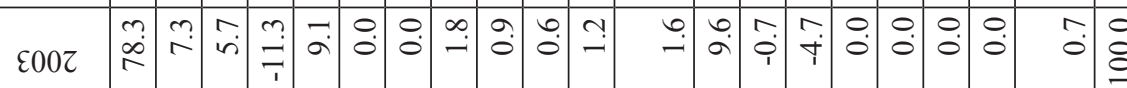

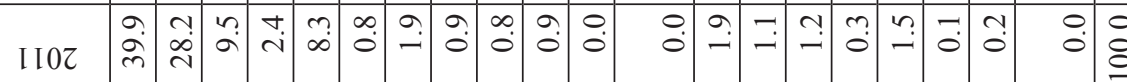

ชิ

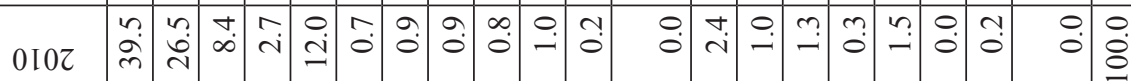

6002 穴

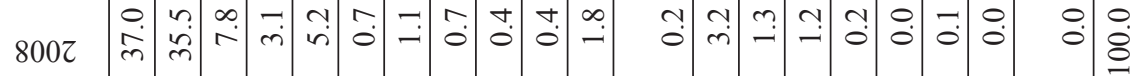

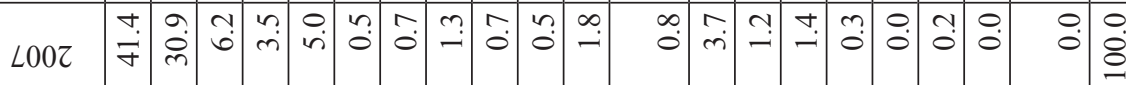

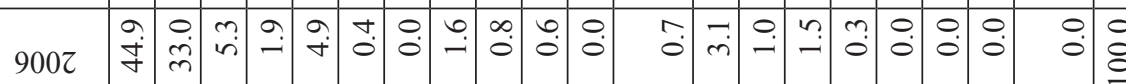

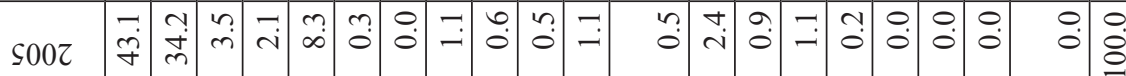

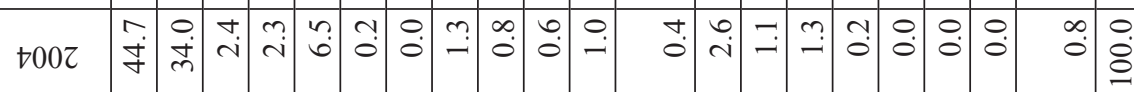
$\varepsilon 00 z$

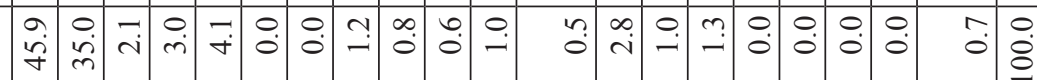




\section{Changes In EFFECTIVEnESS OF IT CORPORATIONS BY COUNTRIES}

The corporations analysed in the paper did not demonstrate the same effectiveness, which is expressed by the sales value per corporation ratio. The years 2003-2011 saw doubled effectiveness of the IT corporations as the value of the ratio grew from 13.2 billion USD to 26.4 billion USD per 1 corporation.

A Finland-based corporation reported the highest sales effectiveness increasing the ratio from USD 37.1 billion to USD 50.1 billion, seconded by corporations from South Korea with their ratio going up from USD 27.1 billion to USD 54.9 billion. USA and Japan-based corporations proved important in this respect, generating the highest ratios. The average sales per 1 corporation ratio in the USA and Japan went up in the period from USD 11.7 billion and 19.3 billion in 2003 to USD 25.37 billion and 35.4 billion in 2011, respectively (Fig. 4). In addition, Taiwan-based corporations reported a major growth of sales, increasing the ratio from USD 3.5 billion to USD 27.8 billion.

This shows that corporations based in the countries reporting the highest concentration of IT corporate headquarters and corporations demonstrating exceptional competition of their products on the market, e.g. Nokia from Finland, were the most effective.

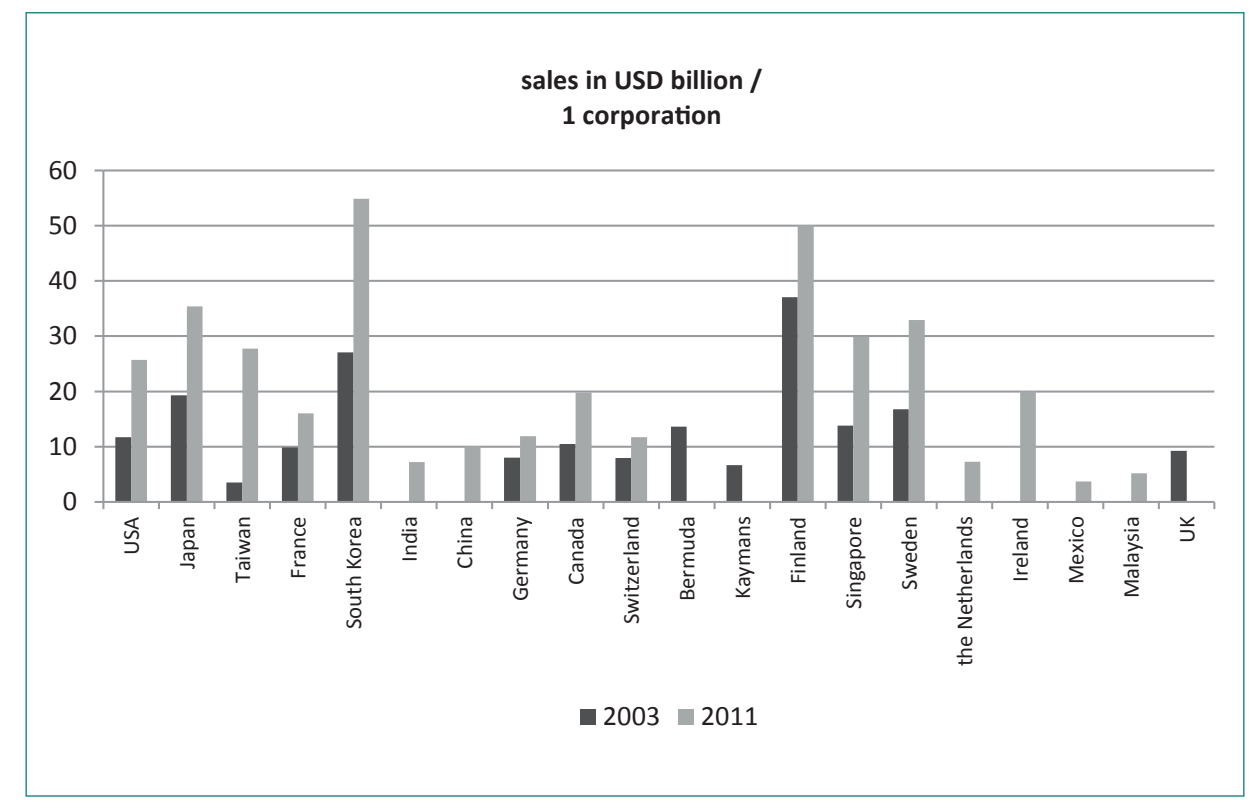

Fig. 4. Sales per 1 corporation ratio for IT corporations in years 2003-2011, by countries

Source: own study 


\section{Changes IN PROFIT VALUE OF IT CORPORATIONS BY COUNTRIES}

From the economic point of view, the value of profits is of major importance for the position and growth opportunities of corporations. From 2003 to 2011, the profit of all the researched corporations grew from USD 37.1 billion to USD 222.8 billion, i.e. up to $473.0 \%$. At the same time, the leading IT corporations reported a drop in their profits in the total leading IT corporations from $99.5 \%$ in 2003 to $85.6 \%$ in 2011 . Their overall profit ranged therefore from USD 16.9 billion of loss to USD 156.3 billion of profit, depending on a country.

Similarly to the sales value structure, the profit value structure displayed the dominance of USA-based corporations with their profits growing from USD 36.9 billion to USD 156.3 billion, i.e. up to $424.0 \%$, but their share in the total profit value was reduced from $78.3 \%$ to $70.2 \%$ (Fig. 5). In 2003, countries reported different value of profits and their share ranged from $5 \%$ to $10 \%$ in corporations headquartered in Finland, Japan, Taiwan and South Korea. Lower shares in total profits (below 2\%) were typical for corporations from: Germany, Canada, Switzerland, the Bermudas, the Cayman Islands and the UK. Losses were reported by corporations headquartered in France, Sweden and Singapore. The structure changed to some extent in subsequent years due to profit growth fluctuations.

Between years 2003-2011, the highest profit growth was reported by India and Germany-based IT corporations, with their profits going up to $712.1 \%$ and $705.0 \%$ respectively, and corporations based in Switzerland and Canada (up to $642.9 \%$ and 536.6\%). USA, Taiwan and South Korea-based corporations displayed a steady growth of profit. Japanese corporations reported some considerable changes in their profits, which fluctuated from USD 16.9 billion of a loss in 2009 to USD 27.0 billion of profit in 2008. The economic crisis affected profit growth rate considerably and, in particular, influenced their plummeting in 2008 and 2009 followed by their rapid rebound. However, some countries, e.g. the USA or India, had favourable conditions leading to growing profits of the corporations in spite of the economic global downturn.

In 2011, the profit structure continued to be dominated by USA-based corporations, representing $70.2 \%$ of the profit value. Japanese corporations came second, with $7.5 \%$ of profits followed by corporations from South Korea (4.6\%), Taiwan (4.1\%), Germany (2.7\%) and Ireland, India, France, China, Canada, Switzerland, Singapore, Sweden, the Netherlands, Mexico and Malaysia. Only the Finland-based corporation reported losses in 2011.

The above shows that corporations headquartered in the USA reported the highest profitability, also as a result of the management style preferred in American corporations emphasising the best possible financial performance. USA-based global corporations prevail in the ranking, largely in consequence of the biggest number of the corporations headquartered in the USA. 


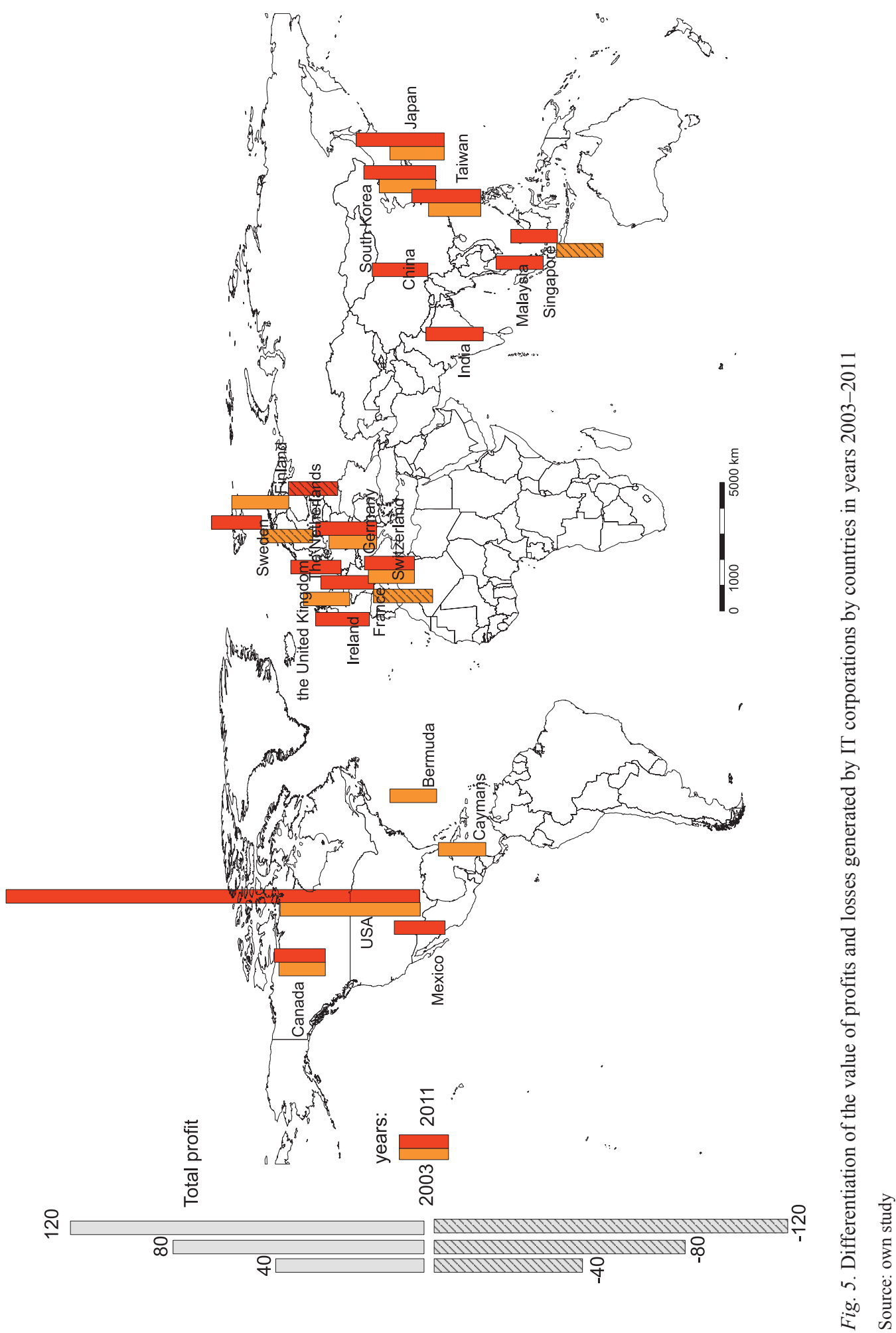




\section{Changes in the ASSET VAlue of IT CORPORATIONS By COUNTRIES}

The analysed companies reported a lower growth in the value of their assets. From 2003 to 2011 , their value grew from USD $1,500.5$ billion to USD $2,868.3$ billion, i.e. up to $185.0 \%$ (Tab. 3). The share of the leading IT corporation in the total global IT corporations in terms of their asset value fluctuated from $86.5 \%$ in 2009 to $92.3 \%$ in 2011 .

In line with other results, the highest asset value was reported by USA-based corporations, with their asset value going up from USD 811.4 billion to USD 1309.5 billion, i.e. up to $161.4 \%$ and their share in the total value of the analysed corporations went down from $52.3 \%$ to $45.7 \%$ and Japan with their assets going up from USD 473.7 billion to USD 812.3 billion, i.e. to $171.5 \%$ (Fig. 6). The assets reported by corporations from other countries in the same period were significantly lower, ranging from USD 2.1 billion to USD 255.0 billion. Corporations headquartered in the Cayman Islands and the Netherlands reported the lowest value of their assets.

In the analysed period, the growth of the asset value was fluctuating heavily, but Taiwan and South Korea-based corporations reported the highest growth in the value of their assets, such as $461.8 \%$ and $307.1 \%$, respectively. Corporations headquartered in Germany, Switzerland, Sweden, Finland, France, Canada, Japan and the USA displayed high growth (up to 200\%). On the other hand, Bermuda-based corporations reported a drop in the value of their assets.

In 2003, in the asset structure, apart from USA-based corporations, which reported assets representing $532.3 \%$ of the total assets held by the analysed corporations, as it was the case in sales, Japanese corporations took the lead with their assets representing $30.6 \%$ of total assets (Tab. 4). In total, the countries held $82.9 \%$ of the asset value of the dominant IT corporations. Corporations headquartered in other countries reported shares below $5 \%$, jointly representing $17.1 \%$ of total assets of the leading IT corporations.

In 2011, assets of IT corporations were largely dispersed; however, the structure remained dominated by corporations based in the USA, with $45.7 \%$ of the total assets and Japanese corporations holding $28.3 \%$ of total assets. South Korean and Taiwanese corporations followed with their share at $12.8 \%$ of the total assets. The share of corporations from other countries was significantly lower (below 3\%), but jointly represented $13.2 \%$ of the total leading IT corporations.

Again, in terms of the value of their total assets, as in the case of other metrics discussed in the paper, concentration is observed in the corporations headquartered in the USA and Japan. The value of the metric is largely dependent on the type of business run by corporations headquartered in specific countries, as service corporations would display a considerably lower value of assets than purely production corporations.

Dispersion of assets in the analysed corporations globally was affected by an increase in the number of countries where they are headquartered, as in 2003 IT corporations were headquartered in 14 countries, while in 2011 in 17. This is an indication of new emerging markets offering favourable conditions for setting up and growing IT corporations. 


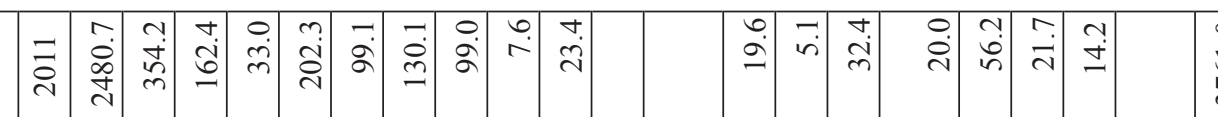

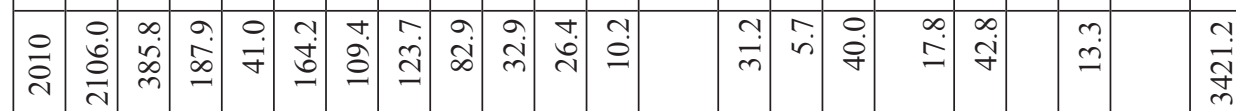

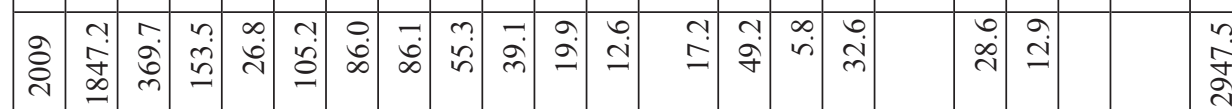

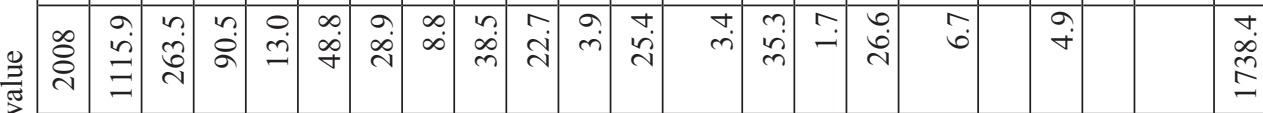

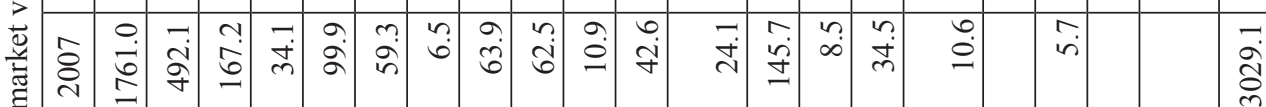

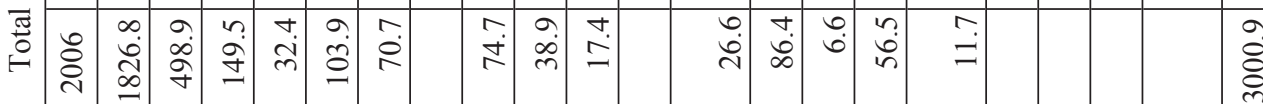

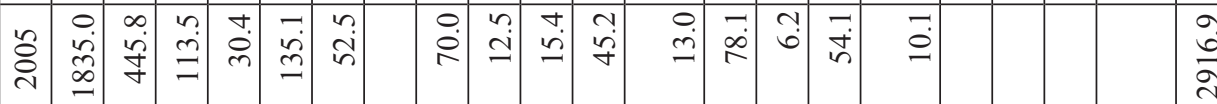

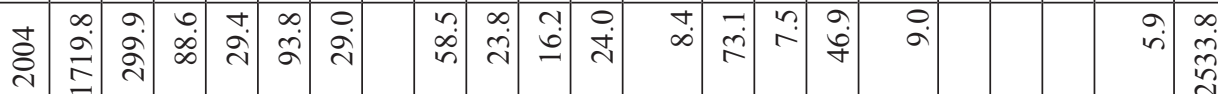

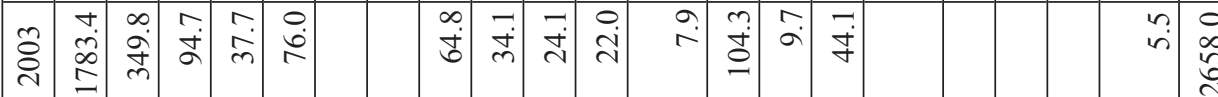

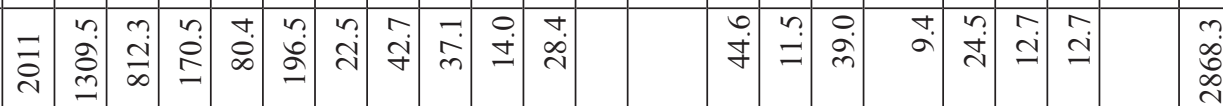

$\vec{\Xi}$

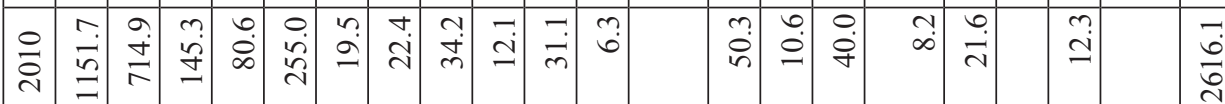

ชి

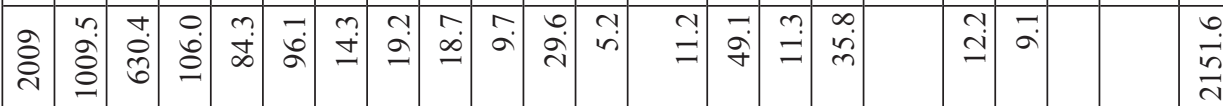




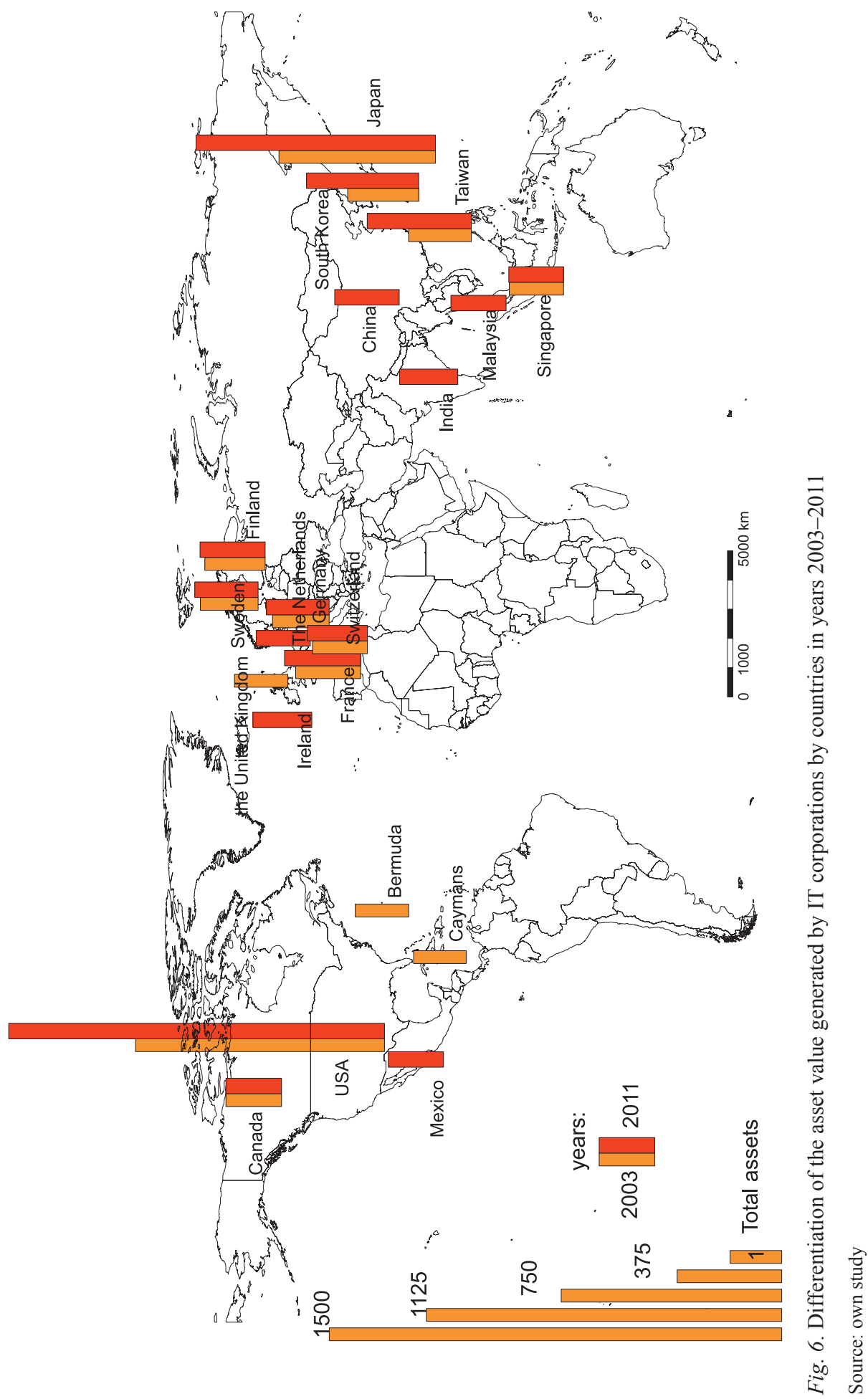




\begin{tabular}{|c|c|c|c|c|c|c|c|c|c|c|c|c|c|c|c|c|c|c|c|c|c|c|}
\hline \multirow{9}{*}{ 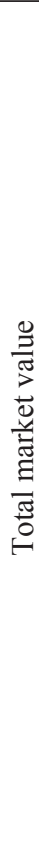 } & $\overrightarrow{\bar{d}}$ & $\begin{array}{l}0 \\
\ddot{\theta}\end{array}$ & $\stackrel{\nabla}{\sigma}$ & $\stackrel{?}{\nabla}$ & $\grave{0}$ & $\begin{array}{c}\dot{\nabla} \\
\dot{n}\end{array}$ & $\begin{array}{l}0 \\
i\end{array}$ & $\begin{array}{c}n \\
n\end{array}$ & $\begin{array}{l}\overrightarrow{0} \\
\stackrel{\sim}{*}\end{array}$ & $\stackrel{1}{0}$ & $\begin{array}{l}0 \\
\stackrel{0}{0}\end{array}$ & $\stackrel{0}{0}$ & $\because$ & 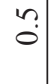 & $\overrightarrow{0}$ & $\ddot{0}$ & $\because$ & $\stackrel{n}{-}$ & $\begin{array}{l}0 \\
\dot{0}\end{array}$ & $\dot{0}$ & $\stackrel{0}{\circ}$ & $\begin{array}{l}0 \\
\dot{0} \\
\end{array}$ \\
\hline & $\begin{array}{l}\circ \\
\stackrel{0}{0}\end{array}$ & $\begin{array}{l}0 \\
\\
\end{array}$ & $\stackrel{?}{=}$ & $\begin{array}{l}n \\
n\end{array}$ & בִ & $\begin{array}{l}\infty \\
\dot{+}\end{array}$ & ñ. & $\begin{array}{c}0 \\
\dot{m}\end{array}$ & $\stackrel{+}{\mathrm{i}}$ & 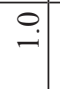 & $\begin{array}{l}\infty \\
0 \\
0\end{array}$ & $?$ & $\stackrel{0}{0}$ & $\dot{0}$ & ণั) & ণ & $\because$ & $?$ & $\stackrel{0}{0}$ & $\dot{0}$ & $\begin{array}{l}0 \\
0\end{array}$ & $\begin{array}{l}0 \\
8 \\
8\end{array}$ \\
\hline & ஓे & ชิ & $\begin{array}{l}n \\
\mathfrak{I} \\
-\end{array}$ & in & $\dot{0}$ & $\begin{array}{l}0 \\
\dot{r}\end{array}$ & $\hat{\mathrm{i}}$ & $\hat{\mathrm{i}}$ & 9 & 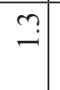 & $\ddot{0}$ & $\stackrel{+}{\circ}$ & $\begin{array}{l}0 \\
\dot{0}\end{array}$ & I & गั & ت & $\stackrel{0}{\circ}$ & $\stackrel{-}{-}$ & $\stackrel{+}{0}$ & $\dot{0}$ & $\stackrel{\circ}{\circ}$ & $\begin{array}{l}0 \\
\dot{8} \\
\end{array}$ \\
\hline & $\stackrel{\infty}{8}$ & プ & $\begin{array}{l}\text { ำ } \\
\stackrel{n}{n}\end{array}$ & ì & $\tilde{0}$ & $\begin{array}{l} \\
\\
\mathrm{i}\end{array}$ & 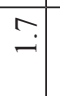 & \begin{tabular}{|l|}
$n$ \\
\end{tabular} & $\begin{array}{c}\mathrm{N} \\
\mathrm{N}\end{array}$ & $?$ & ก̋ & $\stackrel{n}{n}$ & กั & $\stackrel{\circ}{i}$ & $\overrightarrow{0}$ & $\cong$ & $\stackrel{t}{0}$ & $\stackrel{\circ}{\circ}$ & 3 & $\stackrel{0}{0}$ & $\stackrel{\circ}{\circ}$ & $\begin{array}{l}0 \\
\dot{8} \\
\end{array}$ \\
\hline & 웡 & $\vec{\infty}$ & ชֶ & $\begin{array}{l}n \\
i n\end{array}$ & $\exists$ & $m$ & $\begin{array}{l}0 \\
i\end{array}$ & $\begin{array}{l} \\
\end{array}$ & $\overrightarrow{\mathrm{i}}$ & $\overrightarrow{\mathrm{i}}$ & $\stackrel{+}{\circ}$ & $\stackrel{+}{-}$ & $\stackrel{\infty}{0}$ & $\begin{array}{l}\infty \\
\dot{\sim} \\
\end{array}$ & ?! & $\exists$ & $\dot{0}$ & $\stackrel{\circ}{\circ}$ & $\tilde{o}$ & $\begin{array}{l}0 \\
0\end{array}$ & $\stackrel{\circ}{\circ}$ & $\begin{array}{l}0 \\
\dot{8} \\
\end{array}$ \\
\hline & ¿ & $\begin{array}{l}0 \\
8\end{array}$ & 它 & $\begin{array}{l}0 \\
\text { in }\end{array}$ & $\exists$ & $\ddot{n}$ & $\stackrel{{ }_{i}}{\mathrm{i}}$ & $\begin{array}{l} \\
\end{array}$ & $\begin{array}{ll}n \\
\end{array}$ & $?$ & $\begin{array}{l}0 \\
\\
\end{array}$ & $\stackrel{\circ}{\circ}$ & $\dot{0}$ & $\overrightarrow{\mathrm{i}}$ & N̦ & 9 & $\dot{+}$ & $\begin{array}{l}0 \\
0\end{array}$ & $\stackrel{0}{0}$ & $\begin{array}{l}0 \\
0\end{array}$ & $\begin{array}{l}0 \\
\end{array}$ & $\begin{array}{l}0 \\
\stackrel{8}{\circ}\end{array}$ \\
\hline & $\stackrel{n}{8}$ & ชิ & $\stackrel{m}{n}$ & के & $\stackrel{-}{0}$ & $\begin{array}{l} \\
\dot{+}\end{array}$ & $\stackrel{\infty}{-\infty}$ & \begin{tabular}{l|}
0 \\
\end{tabular} & 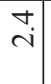 & $\dot{0}$ & ?ִ & $\stackrel{n}{-}$ & $\stackrel{+}{\circ}$ & $\vec{i}$ & $\begin{array}{l} \\
\end{array}$ & 9 & $?$ & $\begin{array}{l}0 \\
\dot{0}\end{array}$ & $\stackrel{0}{\circ}$ & $\begin{array}{l}0 \\
0\end{array}$ & $\begin{array}{l}0 \\
\end{array}$ & \begin{tabular}{|l|}
0 \\
$\dot{0}$ \\
\end{tabular} \\
\hline & 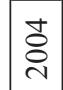 & $\frac{a}{6}$ & $\stackrel{\infty}{=}$ & $\stackrel{n}{m}$ & בִ & $\dot{r}$ & $\rightrightarrows$ & \begin{tabular}{l|}
0 \\
\end{tabular} & $\stackrel{m}{n}$ & $\begin{array}{l}0 \\
0\end{array}$ & $\begin{array}{l} \\
\\
0\end{array}$ & $\overrightarrow{0}$ & $?$ & $\overrightarrow{\mathrm{i}}$ & ? & $\stackrel{\infty}{-\infty}$ & $\dot{+}$ & $\begin{array}{l}0 \\
\end{array}$ & $\stackrel{\circ}{\circ}$ & $\begin{array}{l}0 \\
\end{array}$ & $\stackrel{1}{0}$ & $\begin{array}{l}0 \\
8 \\
8\end{array}$ \\
\hline & 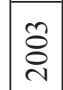 & $\sqrt{6}$ & $\stackrel{\sim}{\simeq}$ & $\begin{array}{l}\dot{0} \\
\dot{m}\end{array}$ & $\stackrel{+}{-}$ & $\widehat{\mathrm{i}}$ & $\stackrel{0}{0}$ & $\stackrel{0}{0}$ & $\stackrel{+}{\mathrm{i}}$ & $?$ & $\dot{0}$ & $\stackrel{\infty}{0}$ & $?$ & $\dot{m}$ & $\stackrel{+}{\circ}$ & I. & $\stackrel{0}{\circ}$ & $\stackrel{0}{\circ}$ & $\stackrel{0}{0}$ & $\stackrel{\circ}{0}$ & กุ & $\begin{array}{l}0 \\
\stackrel{8}{\circ}\end{array}$ \\
\hline \multirow{9}{*}{ 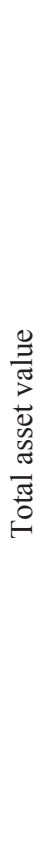 } & $\overline{\vec{\sim}}$ & $\dot{\gamma}$ & $\begin{array}{l}m \\
\stackrel{\infty}{\sim}\end{array}$ & iे & $\begin{array}{l}\infty \\
\sim\end{array}$ & बे. & $\begin{array}{l}\infty \\
0 \\
0\end{array}$ & $\because$ & 9 & $\because$ & ㅇ. & $\stackrel{0}{0}$ & $\stackrel{0}{0}$ & 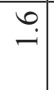 & $\stackrel{+}{\circ}$ & $\stackrel{+}{-}$ & $?$ & $\hat{0}$ & $\stackrel{+}{0}$ & $\stackrel{+}{\circ}$ & $\stackrel{0}{0}$ & $\begin{array}{l}0 \\
\dot{8} \\
\end{array}$ \\
\hline & $\begin{array}{l}\stackrel{0}{\circ} \\
\stackrel{\sim}{\circ}\end{array}$ & 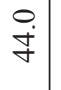 & $\stackrel{m}{\sim}$ & $\begin{array}{l}0 \\
i \\
i\end{array}$ & $\vec{m}$ & $\hat{a}$ & $\tilde{0}$ & $\grave{0}$ & $\dddot{-}$ & $\because$ & 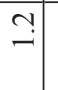 & กั. & $\begin{array}{l} \\
\end{array}$ & 9 & $\dot{0}$ & $\because$ & 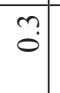 & $\begin{array}{l}\infty \\
0 \\
0\end{array}$ & $\stackrel{0}{0}$ & $\because$ & $\stackrel{\circ}{\circ}$ & \begin{tabular}{|l|}
$\circ$ \\
$\dot{8}$ \\
\end{tabular} \\
\hline & 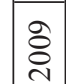 & ఫे & ते & $\begin{array}{l}\dot{\sigma}^{\prime} \\
\end{array}$ & $\hat{r}$ & $\because$ & $\overrightarrow{0}$ & $\hat{0}$ & $\dot{0}$ & $\because$ & $\stackrel{+}{-}$ & กั & $\dddot{n}$ & $\stackrel{m}{i}$ & $\because$ & 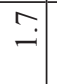 & $\begin{array}{l}0 \\
0\end{array}$ & $\begin{array}{l}0 \\
\dot{0}\end{array}$ & $\stackrel{+}{0}$ & $\stackrel{\circ}{\circ}$ & $\begin{array}{l}0 \\
0\end{array}$ & \begin{tabular}{|c|}
0 \\
$\dot{0}$ \\
\end{tabular} \\
\hline & 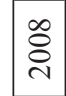 & 高 & $\stackrel{\sim}{+}$ & $\begin{array}{l}\infty \\
i \\
i\end{array}$ & 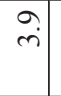 & $m$ & $\begin{array}{l}0 \\
0 \\
0\end{array}$ & 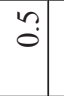 & $\grave{0}$ & $?$ & $\begin{array}{l}0 \\
\dot{0}\end{array}$ & $\stackrel{+}{-}$ & $\overrightarrow{0}$ & $\stackrel{+}{i}$ & $\dot{0}$ & 苗 & $\stackrel{1}{0}$ & $\begin{array}{l}0 \\
0\end{array}$ & $?$ & $\stackrel{0}{0}$ & $\stackrel{0}{0}$ & $\begin{array}{l}0 \\
\dot{8}\end{array}$ \\
\hline & 횽 & $\begin{array}{l}\infty \\
\dot{\gamma}\end{array}$ & $\overrightarrow{0}$ & in & $?$ & $\stackrel{\vartheta}{+}$ & $\stackrel{+}{\circ}$ & $\ddot{0}$ & $\stackrel{+}{-}$ & ○. & $\hat{0}$ & $\exists$ & $\grave{0}$ & $\tilde{i}$ & $\hat{\sigma}$ & $\Xi$ & $?$ & $\stackrel{0}{0}$ & $\stackrel{+}{0}$ & $\stackrel{0}{0}$ & $\stackrel{0}{0}$ & \begin{tabular}{|c|} 
\\
\\
0
\end{tabular} \\
\hline & 号 & $\begin{array}{l}0 \\
\dot{\infty} \\
+\end{array}$ & $\stackrel{0}{\dot{m}}$ & $\vec{n}$ & ָָ & $\because$ & $?$ & $\stackrel{\circ}{0}$ & \begin{tabular}{l|}
$\infty$ \\
\end{tabular} & $\hat{0}$ & $\begin{array}{l}\infty \\
0 \\
0\end{array}$ & $\stackrel{0}{0}$ & $\begin{array}{l}0 \\
0\end{array}$ & ب0 & $\tilde{0}$ & $\stackrel{0}{0}$ & 3 & $\stackrel{\circ}{\circ}$ & $\stackrel{0}{0}$ & $\stackrel{0}{0}$ & $\stackrel{\circ}{0}$ & \begin{tabular}{|l|}
$\circ$ \\
$\dot{8}$ \\
\end{tabular} \\
\hline & $\stackrel{n}{0}$ & $\frac{0}{\tilde{\gamma}}$ & $\begin{array}{l}0 \\
\text { i } \\
n\end{array}$ & $\begin{array}{l}\dot{\varphi} \\
\dot{r}\end{array}$ & $\stackrel{m}{\mathrm{i}}$ & $\stackrel{+}{\bullet}$ & $\stackrel{\sim}{0}$ & $\stackrel{0}{\circ}$ & ִָ & $\hat{0}$ & $\ddot{0}$ & $\ddot{0}$ & $\tilde{m}$ & $\stackrel{+}{-}$ & $\begin{array}{l}0 \\
0 \\
0\end{array}$ & $\stackrel{+}{-}$ & $\widetilde{o}$ & $\stackrel{0}{0}$ & $\stackrel{0}{0}$ & $\stackrel{0}{0}$ & $\because$ & $\begin{array}{l}0 \\
\dot{8}\end{array}$ \\
\hline & 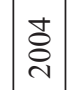 & $\stackrel{n}{q}$ & $\stackrel{?}{m}$ & $\tilde{i}$ & $\hat{i}$ & $\begin{array}{l}n \\
n \\
\end{array}$ & $\overrightarrow{0}$ & $\stackrel{\circ}{\circ}$ & 节 & $\hat{0}$ & $\stackrel{\infty}{0}$ & 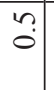 & 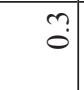 & $\stackrel{\infty}{-}$ & $\tilde{0}$ & $\because$ & ำ & $\stackrel{\circ}{\circ}$ & $\stackrel{0}{0}$ & $\begin{array}{l}0 \\
0\end{array}$ & $\dot{0}$ & \begin{tabular}{|l|}
0 \\
8 \\
\end{tabular} \\
\hline & 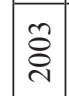 & ñ & $\begin{array}{l}0 \\
\dot{0}\end{array}$ & $\stackrel{\vec{i}}{\mathrm{i}}$ & $\hat{\sim}$ & $\overrightarrow{+}$ & $\begin{array}{l}0 \\
0\end{array}$ & $\begin{array}{l}0 \\
0\end{array}$ & 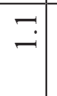 & $\hat{0}$ & $\stackrel{\infty}{0}$ & $\stackrel{+}{\circ}$ & 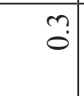 & 9 & $\begin{array}{l}0 \\
0\end{array}$ & $\stackrel{+}{-}$ & $\stackrel{0}{0}$ & $\begin{array}{l}0 \\
0\end{array}$ & $\stackrel{0}{0}$ & $\begin{array}{l}0 \\
0\end{array}$ & $\stackrel{+}{0}$ & \begin{tabular}{|l|}
0 \\
\\
0
\end{tabular} \\
\hline \multicolumn{2}{|c|}{ 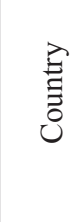 } & 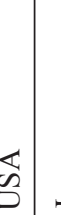 & 甯. & 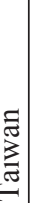 & 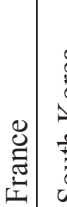 & \multicolumn{2}{|c|}{ 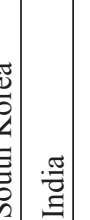 } & 竘 & 0 & 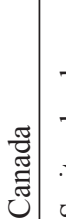 & 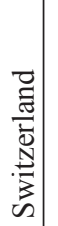 & 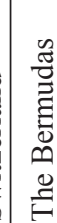 & 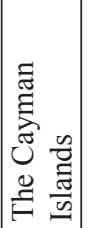 & 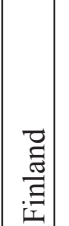 & \multicolumn{2}{|c|}{ 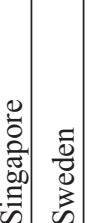 } & 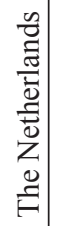 & \multicolumn{2}{|c|}{ 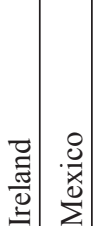 } & $\frac{\sqrt[\pi]{n}}{\stackrel{\pi}{\pi}}$ & 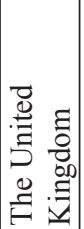 & $\begin{array}{l}\bar{\pi} \\
0 \\
0\end{array}$ \\
\hline
\end{tabular}




\section{Changes IN THE MARKET VALUE OF IT CORPORATIONS BY COUNTRIES}

The changing performance of the leading IT corporations is manifested through fluctuations of their market value - from 2003 to 2011 - increasing from USD 2,658.0 billion to USD 3.761 .0 billion, i.e. up to $141.5 \%$. The share of the leading corporations in the total global IT corporations in the analysed period ranged from $88.1 \%$ to $91.4 \%$.

The US-based corporations reported the highest market value, which grew from USD $1,783.4$ billion to USD $2,480.7$ billion, i.e. up to $139.1 \%$. The market values of the corporations headquartered in other countries ranged from USD 3.4 billion to USD 369.7 billion (Fig. 7).

The market value fluctuated in the analysed period in respective countries. France-based corporations reported a significant drop in the market value (from USD 37.7 billion to 33.0 billion) followed by Canadian (from USD 34.1 billion to USD 7.6 billion ), Finnish (from USD 104.3 billion to USD 19.6 billion), Swiss, Singapore and Swedish corporations.

Two years: 2004 and 2008, stand out among growth figures - these were the years of a reduced market value of the analysed corporations below the level of 2003 in most countries. In 2004, the value of the growth, depending on a country, ranged from $69.8 \%$ to $123.5 \%$ and in 2008 from $16.1 \%$ to $115.2 \%$, which came first as a result of the sectoral fluctuations and then the outcome of the global economic crisis.

In the market value structure of IT corporations in 2003, the highest share was reported for USA-based corporations, totalling $67.1 \%$ of the market value and Japan-based corporations, totalling $13.2 \%$. They jointly held $80.3 \%$ of the total market value. Corporations from other countries represented less than $4 \%$ in the structure, holding jointly $19.7 \%$ of the value and corporations from Finland, Taiwan and South Korea reported the largest share $-3.9 \%$ $3.6 \%$ and $2.9 \%$, respectively.

Similarly, 2011 saw the dominance of American corporations, holding $66 \%$ of the total market value of all corporations and the dominance of Japanese corporations holding $9.4 \%$ of the share. Together with the growing share of corporations from South Korea (to 5.4\%), Taiwan (to 4.3\%), the importance of China, India and Ireland-based corporations went up (to $3.5 \%, 2.6 \%$ and $1.35 \%$ of the total, respectively) as well.

In terms of their market value, IT corporations demonstrated a considerable dependence on global market trends, as in the case of profits. The years 2008-2009 saw a major drop in the value of the leading IT corporations (and all corporations operating in the IT sector). However, contrary to corporations from other sector, they experienced the crisis for a relatively short time and as early as in 2010 their total market value increased significantly. The analysed corporations did not have an identical response to the downfall of the global market in each country. Some corporations, taking different actions responding to the crisis, did not report any significant changes in their market value while Europe- and Canada-based corporations reported considerable losses in this respect, which is an indication of their relatively poor standing. 


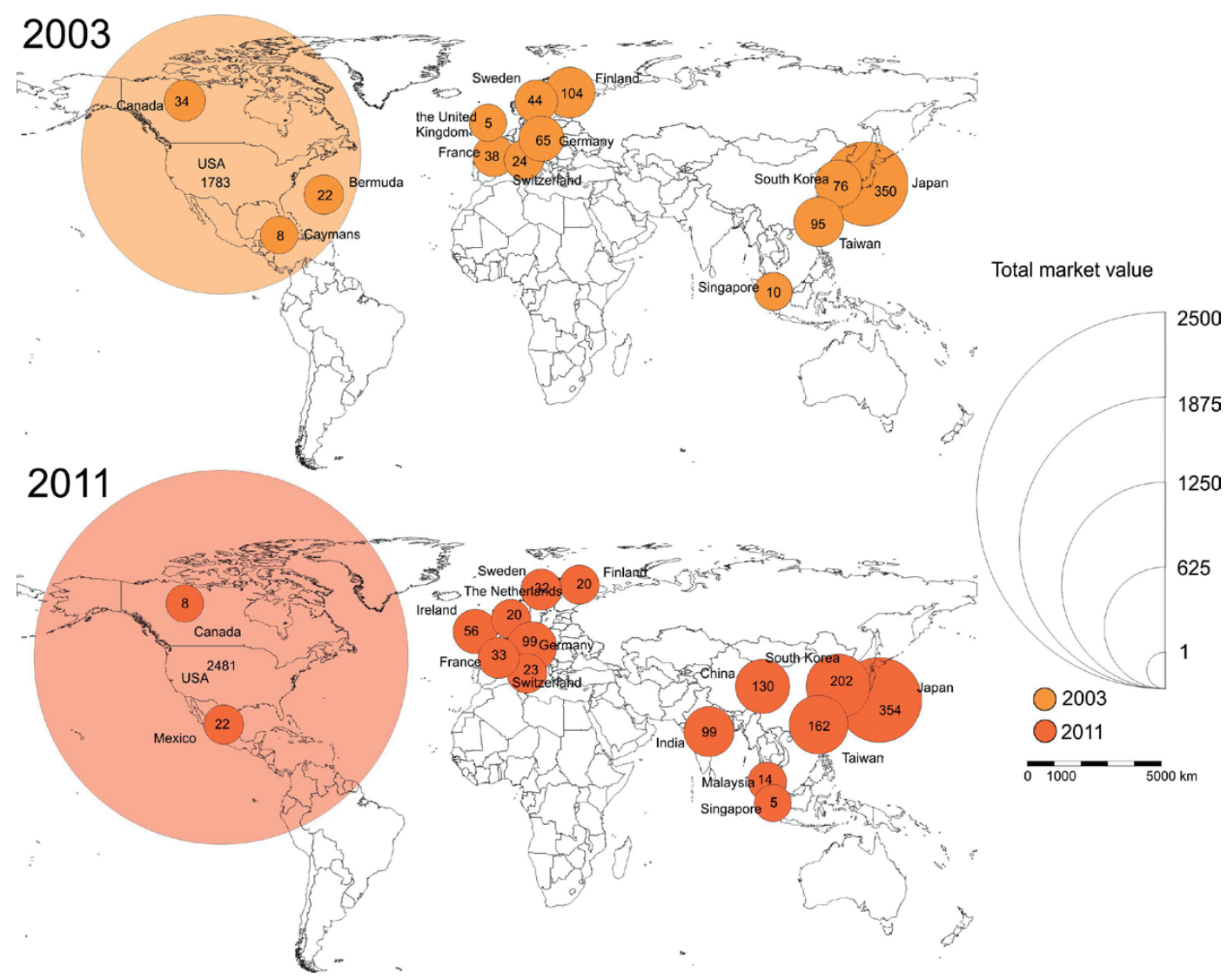

Fig. 7. Differentiation of the market value generated by IT corporations by countries in years 2003-2011

Source: own study

Conclusions

To summarize, from 2003 to 2011, the IT corporations with their headquarters in the USA, Japan and Taiwan dominated in terms of importance, as these countries created the best conditions for their operations. Of European countries, the highest number of company headquarters was reported in France, Germany and Switzerland. An analysis of the economic potential indicator shows that, over that period, IT corporations were subject to continuous dispersion globally. The phenomenon manifested itself by a drop in the number of corporations placing their headquarters in the USA and Japan, which translated into dispersed economic potential that, by the time, had been concentrated in these countries. Furthermore, newly emerging corporations from China, Ireland, India, the Netherlands, Mexico and Malaysia increased their importance in the structure. 
In the analysed period, the total value of sales, assets, profits and the market value of the leading IT corporations grew substantially, however, only the value of the profits and the market value of the analysed corporations decreased considerably in 2008 and 2009, thus indicating the then-occurring global economic crisis. Other business sectors could feel the crisis in their corporate performance for a substantially longer period, while the corporations analysed in the paper reported a very high growth in the value of their economic potential indicator. In spite of the above, it is hard to find good evidence confirming the major impact of the crisis on the spatial deconcentration of IT corporations, as the very process of selecting locations for corporate headquarters is complex and conditional to numerous, also non-economic, factors.

The high degree of economic concentration of IT corporations was confirmed by the synthetic measure ${ }^{11}$ of the potential, calculated on the basis of: the number of corporations, the value of sales and profits, the value of assets and the market value. In 2003, the measure for the USA equalled 59.1 in 2003 and 52.5 in 2011. Although the number of IT corporations having their seats in the USA was globally dominant, their role diminished in the analysed period. IT corporations based in Japan displayed a considerably lower economic potential, as evidenced by the shrinking of the value of the indicator from 22.0 in 2003 to 18.9 in 2011 (Fig. 8). At the same time, the importance of IT corporations from Taiwan and South Korea continued to grow in importance, with their value of the synthetic measure going up from 4.3 and 4.4 to 6.6 and 5.8, respectively. Dispersion of the economic potential of IT corporations came as a result of corporations based in India, China, the Netherlands, Ireland, Mexico and Malaysia joining the group of the dominant corporations, coupled with deteriorating importance of corporations based in the UK, the Cayman Islands and the Bermudas, as in 2011 no IT corporations classified to dominant corporations existed in their area.

The structure of the synthetic measure per country varied considerably (Tab. 5). The value of the synthetic measure in the USA is affected by the value of profits, representing $26.5 \%$ of the structure in 2003 and $26.7 \%$ of the structure in 2011 , and by the market value, representing $22.7 \%$ of the value of the synthetic measure in 2003 and $25.1 \%$ of the measure in 2011. The value of the measure of Japanese corporations was largely influenced by the sales value (3.18\% in 2003 and $29.8 \%$ in 2011) and the asset value (27.8\% in 2003 and $30.0 \%$ in 2011). On the other hand, the volume and value of sales dominated the structure of the synthetic measure of Taiwanese corporations, and the value of sales and asset value dominated the structure of the synthetic measure of South Korean corporations.

Forecasts are that dispersion of the leading IT corporations will continue globally in the years to come. The trend, which has recently emerged, will intensify due to the progressing process of creating IT society and knowledge-based economy in many countries, which creates much better conditions for creating and developing innovative enterprises, i.e. IT corporations. The concentration polars of the analysed corporations in the USA, Japan and Taiwan will be losing their importance in favour of corporations located mainly in China, India and other Asian countries.

11 The synthetic measure was calculated by applying Z. Zioło's method (1972, 1973). 
Usually, countries experiencing concentration of headquarters of dominant IT corporations, typically followed by concentration of their R\&D centres, create the most favourable conditions for their location, in particular because of the environment promoting creation of new knowledge and technology and development of those existing. Factors promoting such concentration include the investment into $R \& D$, substantial employment in the R\&D sector, access to abundant resources of highly-qualified employees and social and economic development of these countries. Other factors affecting location of corporate headquarters and considerable economic potential in these three countries also include: a well-developed ICT infrastructure, access by different means of transport, innovative environment (possibly including special economic zones or enterprise incubators), and development of sectoral specialised clusters of companies operating with broad employment of specific advanced technology, e.g. chips.

In addition, the analysis indicates that, if the conditions existing in European countries continue, the corporations headquartered in Europe will be subject to further marginalisation and their position on the global market will suffer from further deterioration. Nowadays, the analysed corporations are not headquartered outside highly developed countries but their role is decreasing when compared to the role played by other IT corporations. The trend can be overcome only by improving the above-mentioned location factors, which is an exceptionally complex and long-term process. Still, the process is worth initiating as it has multi-dimensional results and affects the social and economic development of the areas which embark on the process.

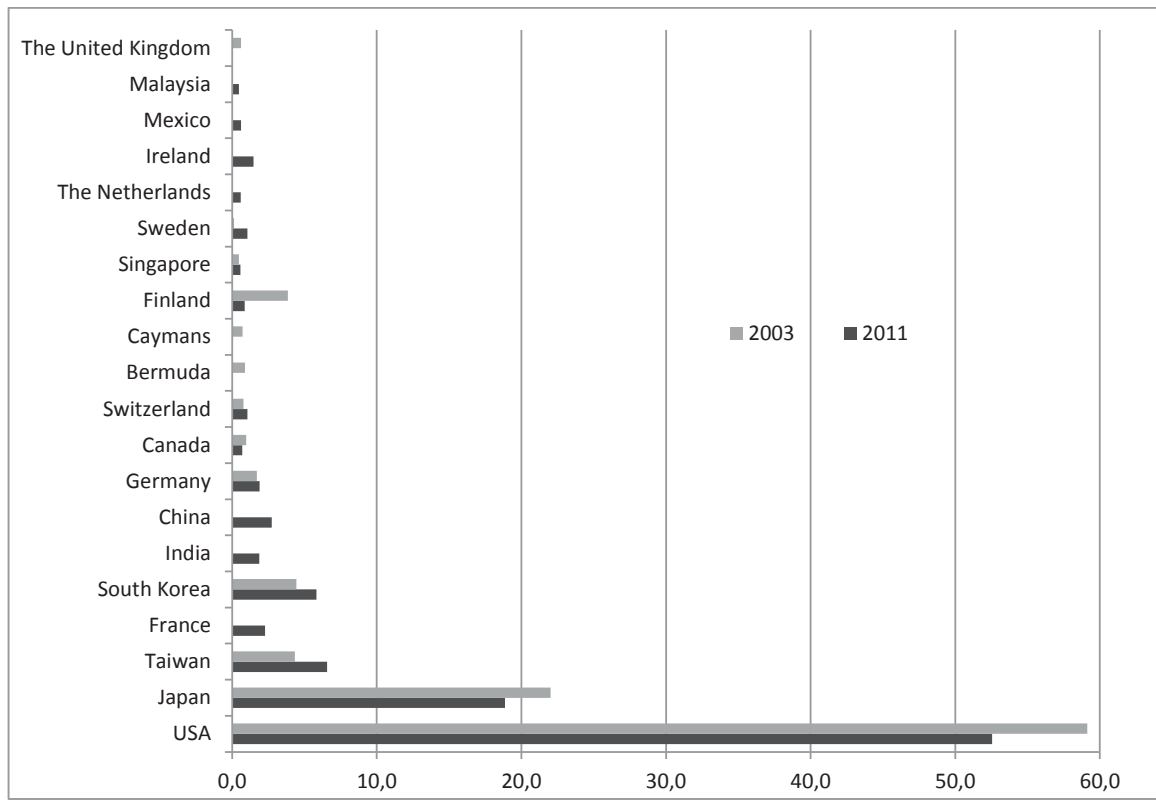

Fig. 8. Differentiation of the synthetic measure of the IT corporation potential by countries in years 2003-2011

Source: own study 


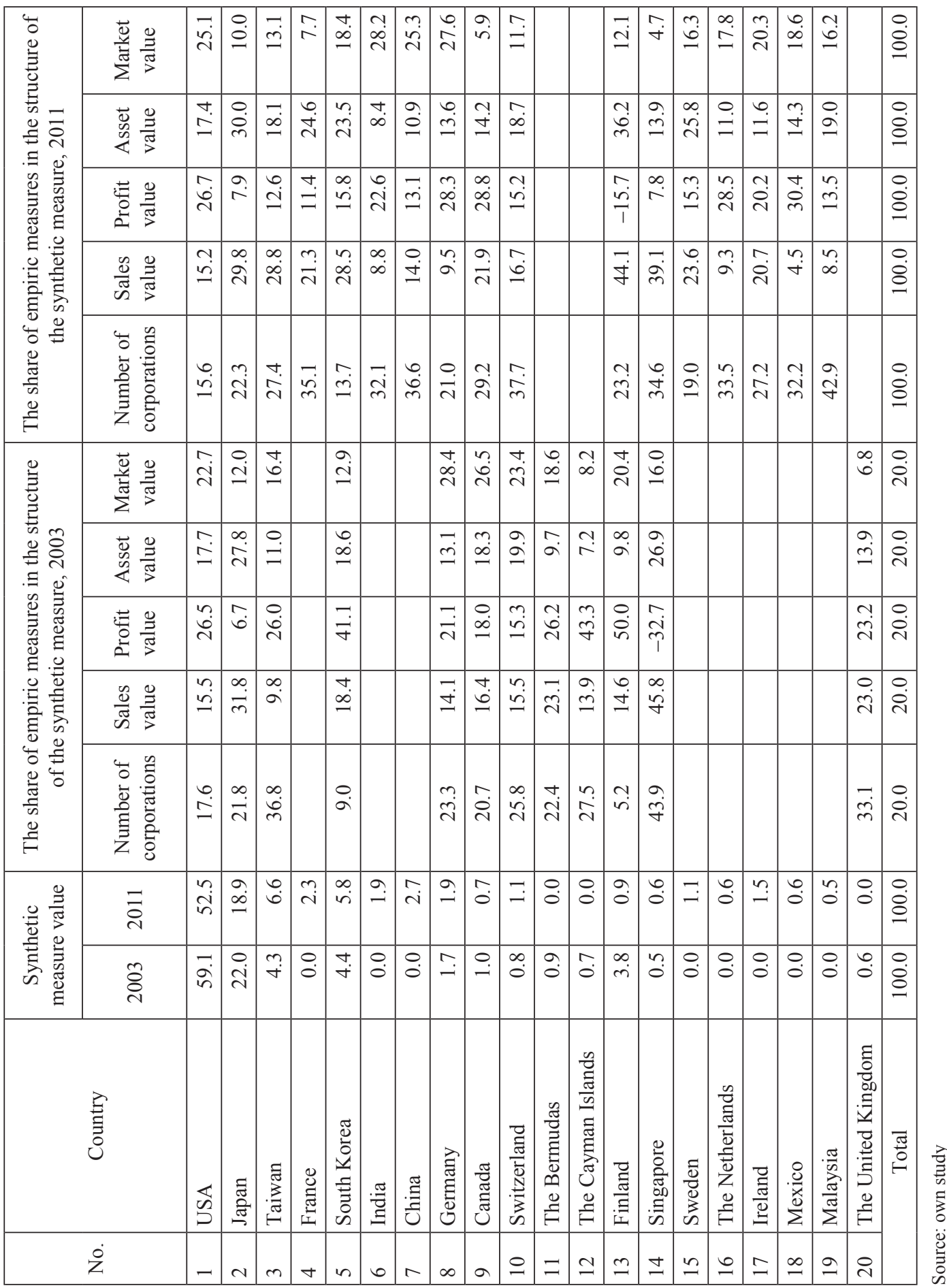




\section{References}

Boguś, M. (2011a). Dynamika potencjału ekonomicznego korporacji ponadnarodowej Google w latach 2001-2009. Prace Komisji Geografii Przemystu Polskiego Towarzystwa Geograficznego, $17,212-224$.

Boguś, M. (2011b). Proces kształtowania się korporacji ponadnarodowej Google. Przedsiębiorczość Edukacja, 7, 128-145.

Bonar, P. (2011). Funkcjonowanie korporacji Ericsson w warunkach globalnego kryzysu gospodarczego. Prace Komisji Geografii Przemystu Polskiego Towarzystwa Geograficznego, 17, 197-211.

Domański, B. (1997). Geografia przedsiębiorstw - niedoceniany nurt badań w polskiej geografii ekonomicznej. In: A. Jackowski, B. Domański (eds.), Geografia, człowiek, gospodarka. Kraków: Uniwersytet Jagielloński, 101-112.

Domański, B. (2002). Zagraniczne inwestycje przemysłowe a obszary metropolitalne w Polsce. Prace Komisji Geografii Przemystu Polskiego Towarzystwa Geograficznego, 4, 9-17.

Dorocki, S. (2010). Współczesne procesy internacjonalizacji produkcji i delokalizacji przemysłu samochodowego Francji. Prace Komisji Geografii Przemystu Polskiego Towarzystwa Geograficznego, $16,125-136$.

Dorocki, S. (2011). Inwestycje zagraniczne we Francji w dobie globalizacji. Przedsiębiorczość Edukacja, 7, 24-41.

Droga Polski do roku 2025. (2005). Warszawa: PAN Komitet Prognoz „Polska 2000 Plus”.

Gierańczyk, W., Stańczyk, A. (2003). Korporacje międzynarodowe w przestrzeni globalnej. Prace Komisji Geografii Przemystu Polskiego Towarzystwa Geograficznego, 5, 73-83.

Hayter, R. (1997). The Dynamics of Industrial Location. The Factory, the Firm and the Producent System. Chichester: John Wiley.

Kilar, W., Cieluch, M. (2008). Kształtowanie się i organizacja przestrzenna korporacji ponadnarodowej Honda. Prace Komisji Geografii Przemystu Polskiego Towarzystwa Geograficznego, 10, $188-203$.

Kilar, W. (2009a). Koncentracja przestrzenna światowych firm informatycznych. Prace Komisji Geografii Przemystu Polskiego Towarzystwa Geograficznego, 12, 97-108.

Kilar, W. (2009b). Zróżnicowanie potencjału ekonomicznego światowych korporacji informatycznych. Prace Komisji Geografii Przemystu Polskiego Towarzystwa Geograficznego, 13, 110-121.

Kilar, W. (2010a). Procesy kształtowania się korporacji Ericsson. Prace Komisji Geografii Przemystu Polskiego Towarzystwa Geograficznego, 16, 153-168.

Kilar, W. (2010b). Zmiany potencjału korporacji informatycznych w Unii Europejskiej w latach 20042008. Przedsiębiorczość - Edukacja, 6, 49-66.

Kilar, W. (2011a). Wpływ kryzysu na funkcjonowanie korporacji Panasonic. Prace Komisji Geografii Przemystu Polskiego Towarzystwa Geograficznego, 17, 187-196.

Kilar, W. (2011b). Kształtowanie się Grupy Samsung w warunkach globalizacji. Przedsiębiorczość Edukacja, 7, 116-127.

Kowalska, K. (2011). Możliwości oceny wpływu bezpośrednich inwestycji zagranicznych w handlu na urzeczywistnianie rozwoju lokalnego i regionalnego. Prace Komisji Geografii Przemystu Polskiego Towarzystwa Geograficznego, 18, 83-91.

Lizak, P. (2010). Działalność japońskich koncernów motoryzacyjnych na terenie Unii Europejskiej jako wyraz atrakcyjności układów regionalnych. Przedsiębiorczość - Edukacja, 6, 66-77.

Micek, G. (2006). Problematyka funkcjonowania firm informatycznych w ujęciu przestrzennym. Prace Komisji Geografii Przemystu Polskiego Towarzystwa Geograficznego, 8, 139-151.

Paszkowski, M. (2008). Kształtująca się gospodarka sieciowa jako pole badawcze geografii przemysłu. Prace Komisji Geografii Przemystu Polskiego Towarzystwa Geograficznego, 11, 40-45.

Płaziak, M., Szymańska, A.I. (2014). Role of modern factors in the process of choosing a location of an enterprise. Procedia - Social and Behavioral Sciences, 120, 72-83. 
Rachwał, T. (2003). Globalne uwarunkowania restrukturyzacji przedsiębiorstw Polski Południowo-Wschodniej. Prace Komisji Geografii Przemystu Polskiego Towarzystwa Geograficznego, 6, $129-138$.

Raźniak, P. (2012). Procesy społeczno-ekonomiczne w Krakowskim Obszarze Metropolitalnym. Prace Geograficzne, 129, 63-81.

Raźniak, P., Winiarczyk-Raźniak, A. (2013). Spatial distribution and differences in migration patterns and revenues of gminas in the Kraków Metropolitan Area. Bulletin of Geography. Socioeconomic Series, 19, 73-86.

Sala, S. (2006). Bezpośrednie inwestycje zagraniczne a procesy globalizacji. Prace Komisji Geografii Przemystu Polskiego Towarzystwa Geograficznego, 8, 80-90.

Stryjakiewicz, T. (1999). Adaptacja przestrzenna przemyshu $w$ Polsce $w$ warunkach transformacji. Poznań: Wydawnictwo Naukowe Uniwersytetu im. A. Mickiewicza.

Stryjakiewicz, T. (2001a). Koncepcja usieciowienia (networking) w badaniach przestrzenno-ekonomicznych. In: H. Rogacki (ed.), Koncepcje teoretyczne i metody badań geografii społeczno-ekonomicznej i gospodarki przestrzennej. Poznań: Bogucki Wydawnictwo Naukowe, 37-47.

Stryjakiewicz, T. (2001b). Orientacje teoretyczno-metodologiczne w geografii przemysłu a transformacja gospodarki. Prace Komisji Geografii Przemystu Polskiego Towarzystwa Geograficznego, $3,13-27$.

Stryjakiewicz, T., Wajda, J. (2003). Organizacja przestrzenna grup kapitałowych jako problem badawczy geografii ekonomicznej. Prace Komisji Geografii Przemystu Polskiego Towarzystwa Geograficznego, 6, 27-48.

Stryjakiewicz, T. (2009). Lokalizacja firm i zachowania przestrzenne pracowników sektora informatycznego (na przykładzie poznańskiego obszaru metropolitalnego). Prace Komisji Geografii Przemystu Polskiego Towarzystwa Geograficznego, 13, 21-33.

Szymańska, A.I. (2005). Pozycja firmy Coca-Cola na polskim rynku napojów gazowanych. Zeszyty Naukowe AE w Krakowie, 659, 165-175.

Szymańska, A.I. (2012). Wpływ innowacyjności na konkurencyjność przedsiębiorstw. In: A. Stabryła, T. Małkus (eds.), Strategie rozwoju organizacji. Kraków: Wydawnictwo Mfiles.pl, 183-197.

Szymańska, A.I., Płaziak, M. (2014). Enterprise and classical factors of its location on the market. Procedia - Social and Behavioral Sciences, 120, 13-22.

Tkocz, M. (2003). Przejawy procesu globalizacji w przemyśle województwa śląskiego. Prace Komisji Geografii Przemystu Polskiego Towarzystwa Geograficznego, 6, 67-76.

Tkocz, M., Żydzik, J. (2010). Rola światowego koncernu w przemianach przestrzeni przemysłowej Polski w okresie transformacji na przykładzie The Coca-Cola Company. Prace Komisji Geografii Przemystu Polskiego Towarzystwa Geograficznego, 16, 169-175.

Wajda, E. (2003). Proces kształtowania się Motoroli jako firmy ponadnarodowej. Prace Komisji Geografii Przemystu Polskiego Towarzystwa Geograficznego, 5, 85-114.

Wajda, E., Zoričič-Wołek, M. (2003). Proces kształtowania się korporacji IBM. Prace Komisji Geografii Przemystu Polskiego Towarzystwa Geograficznego, 6, 109-118.

Wajda, E., Zalewska, K. (2003). Struktura przestrzenno-organizacyjna korporacji General Motors. Prace Komisji Geografii Przemystu Polskiego Towarzystwa Geograficznego, 6, 119-128.

Wajda, E. (2006). Rozwój i struktura przestrzenna działalności Nokii w latach 1997-2003. Prace Komisji Geografii Przemystu Polskiego Towarzystwa Geograficznego, 8, 219-240.

Wieloński, A. (2003). Przemysł Nowej Gospodarki. Prace Komisji Geografii Przemystu Polskiego Towarzystwa Geograficznego, 6, 21-26.

Wieloński, A. (2005). Geografia przemystu. Warszawa: Wydawnictwo UW.

Wilkins, M. (1998). Multinational Corporations. A Historical Account. In: R. Kozul-Wright, R. Rowthorn (eds.), Transnational Corporations and the World Economy. London-New York: Wider-McMillan Press-St. Martin Press. 
World Investment Report 2001(WIR 2001) - Promoting Linkages. New York-Geneva: UNCTAD United Nations.

World Investment Report 2005 (WIR 2005) - Transnational Corporations and the Internationalization of $R \& D$. New York-Geneva: UNCTAD United Nations.

World Investment Report 2006 (WIR 2006) - FDI from Developing and Transition Economies: Implications for Development. New York-Geneva: UNCTAD United Nations.

Wójtowicz, M. (2009). Procesy kształtowania się przemysłu komputerowego Brazylii. Prace Komisji Geografii Przemystu Polskiego Towarzystwa Geograficznego, 13, 133-142.

Wójtowicz, M. (2010). Transformacja i globalna ekspansja brazylijskiego przemysłu lotniczego na przełomie XX i XXI wieku na przykładzie koncernu EMBRAER. Prace Komisji Geografii Przemystu Polskiego Towarzystwa Geograficznego, 16, 137-152.

Zioło, Z. (2001). Struktura branżowa i koncentracja przestrzenna wiodących światowych firm przemysłowych. Prace Komisji Geografii Przemystu Polskiego Towarzystwa Geograficznego, 3, 29-41.

Zioło, Z. (2003). Kształtowanie się przedsiębiorstw przemysłowych w procesie globalizacji. Prace Komisji Geografii Przemystu Polskiego Towarzystwa Geograficznego, 6, 9-20.

Zioło, Z. (2004). Kształtowanie się firm informatycznych jako nowych elementów struktury przestrzennej przemysłu. Prace Komisji Geografii Przemystu Polskiego Towarzystwa Geograficznego, 7, 97-106.

Zioło, Z. (2006a). Zróżnicowanie światowej przestrzeni przemysłowej w świetle koncentracji siedzib zarządów wiodących korporacji. Prace Komisji Geografii Przemystu Polskiego Towarzystwa Geograficznego, 8, 9-26.

Zioło, Z. (2006b). Potencjał ekonomiczny wiodących światowych miast na przełomie wieków. In: B. Górz (ed.), Urbanizacja i społeczeństwo. Kraków: Instytut Geografii Akademii Pedagogicznej w Krakowie, 67-95.

Zioło, Z. (2009a). Procesy kształtowania się światowych korporacji i ich wpływ na otoczenie. Prace Komisji Geografii Przemystu Polskiego Towarzystwa Geograficznego, 12, 11-31.

Zioło, Z. (2011). Wpływ światowego kryzysu na tempo wzrostu gospodarki i światowych korporacji. Prace Komisji Geografii Przemystu Polskiego Towarzystwa Geograficznego, 17, 9-32.

Zioło, Z., Piróg, S. (2002). Lokalizacja zarządów i potencjał ekonomiczny wiodących firm zachodnioeuropejskich. Prace Komisji Geografii Przemystu Polskiego Towarzystwa Geograficznego, 4, 25-36.

Zorska, A. (1998). Ku globalizacji? Przemiany w korporacjach transnarodowych $i$ w gospodarce światowej. Warszawa: Wydawnictwo Naukowe PWN.

Zorska, A. (ed.) (2002). Korporacje międzynarodowe w Polsce. Wyzwania w dobie globalizacji i regionalizacji. Warszawa: Difin.

Zorska, A. (2007). Korporacje transnarodowe. Przemiany, oddziaływania, wyzwania. Warszawa: Polskie Wydawnictwo Ekonomiczne.

Wioletta Kilar, Ph.D., Pedagogical University of Cracow, Institute of Geography, Department of Entrepreneurship and Spatial Management. An economic geographer. A lecturer in the Department of Entrepreneurship and Spatial Management at the Institute of Geography of Pedagogical University of Cracow. The Secretary of the Editorial Board of the Studies of the Industrial Geography Commission of the Polish Geographical Society. She has a considerable experience as a teacher of geography and basics of entrepreneurship, having worked in several secondary schools in Krakow. Her research interests are focused primarily on the processes of formation and operation of multinational corporations, globalization, transformation of spatial structures of industry and the issues of entrepreneurship education issues and geography at school. She is the author of numerous publications in socio-economic geography and entrepreneurship, and many teaching and educational materials and expertises. 


\section{Adres/address:}

Pedagogical University of Cracow

Department of Entrepreneurship and Spatial Management

Institute of Geography

ul. Podchorążych 2, 30-084 Kraków, Poland

e-mail:W.Kilar@up.krakow.pl 